\title{
BRONZE CASTING AND COMMUNICATION IN THE SOUTHEASTERN BALTIC BRONZE AGE
}

\author{
VYTENIS PODE்NAS ${ }^{1}$, AGNĖ ČIVILYTÉ2
}

\author{
${ }^{1}$ Lithuanian Institute of History, Department of Archaeology, Kražių St. 5, 01108 Vilnius, Lithuania, \\ e-mail: vytenispodenas@gmail.com \\ ${ }^{2}$ Lithuanian Institute of History, Department of Archaeology, Kražių St. 5, 01108 Vilnius, Lithuania, \\ e-mail: civilytea@gmail.com
}

The SE Baltic Bronze Age is characterized by a lack of indigenous metalwork traditions as it had been a time when metal finds were predominantly imported or were cast locally, but in foreign styles. This paper analyses the bronze casting remains found in the SE Baltic and discusses the role of these production sites within a wider European network. Through typological identification of the negatives in casting moulds, we assess predominantly Nordic artefact casts, in which the production of KAM (Kel'ty Akozinsko-Melarskie) axes was distinguished at a higher frequency. We hypothesize that several coastal regions were temporarily settled by people of Nordic origin who participated in an exchange with local SE Baltic communities via itinerant bronze production. Foreign settlement areas as indicated by stone ship burials are known in Courland and S Saaremaa as well as in N Estonia and the Sambian Peninsula. From these territories, further communication was developed with local communities settled mostly in enclosed sites in coastal areas and inland, in the vicinity of the River Daugava, the SE Latvian and NE Lithuanian uplands, and the Masurian Lakeland.

Keywords: bronze casting, communication networks, exchange, Southeastern Baltic, Bronze Age.

Pietrytiniame Baltijos jūros regione bronzos amžiuje nesusiformavo savita metalo dirbiniu stilistika, o visa ši laikotarpi vyravo importuoti arba vietoje lieti, bet svetimas formas mégdžiojantys daiktai. Šiame straipsnyje nagrinejami aptariamojo regiono metalo liejybos kompleksai bei keliamas klausimas apie bronzos gamybos vietu vaidmenį to meto Europos prekybinių ryšiu kontekste. Tipologiškai vertinant techninę keramiką išryškèja ǐskkirtinai Šiaurès Europai büdingos formos, tarp kurių vyrauja (Kel'ty Akozinsko-Melarskie) tipo kirviai. Keliama hipotezé, kad kelios pajūrio ruožo gyvenvietès buvo apgyventos laikinai iš Skandinavijos ar Gotlando atvykusiu bendruomeniu, palaikiusiu prekybos ir mainu ryšius su vietinèmis bendruomenèmis. Šios trumpalaikès gyvenvietès lokalizuojamos pagal laivinius kapus, žinomus Kurše, pietinèje Saremos salos dalyje, Šiaurès Estijoje bei Sembos pusiasalyje. Būtent iš šiu vietu toliau organizuotos ekspedicijos po pietryčiu Baltijos regiona, skirtos vystyti kontaktus su vietinèmis bendruomenèmis, ịsikūrusiomis įtvirtintose gyvenvietèse netoli Baltijos jüros ar giliau i žemyninę regiono dali, daugiausiai prie Dauguvos upés, Pietryčiu Latvijoje, šiaurès rytu Lietuvoje ir Mozūrijos ě̌eryne.

Reikšminiai žodžiai: bronzos liejyba, komunikacijos tinklai, mainai, Pietryčių Baltijos jūros regionas, bronzos amžius. 


\section{INTRODUCTION}

The SE Baltic Bronze Age ${ }^{1}$ has recently been distinguished by its late adoption of crop farming circa 1400-1200 cal BC (Piličiauskas et al. 2017; Piličiauskas 2018; Grikpèdis, Motuzaite Matuzeviciute 2018), which was followed by an approximate doubling of bronze consumption (Luchtanas, Sidrys 1999) and the appearance of recurrent bronze casting, thus providing an intriguing case of full Neolithisation and the adoption of Bronze Age innovations in a very short period of time. Current knowledge favours a quick development of agriculture and its intensification in the Late SE Baltic Bronze Age (Minkevičius et al. 2019). However, in contrast to the required sedentary life for cereal and pulse crop cultivation, processing, and storage, the significantly less time-consuming bronze casting activities could have been easily relocated depending on the needs of local communities. This provides several possible models for early metallurgy in the Bronze Age. It had to be dependent on a continuous metal supply from outside the SE Baltic, the development of local specialists, and participation in Pan-European communication networks. This may have been difficult for societies with late technological advancements in sedentary agrarian subsistence economies. Instead, it is important to explore other hypotheses, for example, bronze casters originating from outside the region, and discuss the most likely case according to the known sources.
Research into the Nordic Bronze Age production economic pattern favours a regional division between the rich agropastoral communities in Jutland with significant surplus production. This surplus supported extra-local trading expeditions between regionally established settlements in order to explore other economic values within their catchment areas, such as those found in the forest or along the coasts (Ling et al. 2018). Favourable locations for trade ${ }^{2}$ could have been neutral zones such as the peripheries of the Nordic World where bronze casting sites are found (Jaanusson 1981; Earle et al. 2015; Melheim et al. 2016). The Scandinavians have been attributed an active role in the circum-Baltic communication networks due to their maritime technologies involving boatbuilding and the establishment of stone ship burials that signal their appearance in the SE Baltic (Okulicz 1976; Lang 2007; Wehlin 2013), i.e. the lower River Prieglius (Kaliningrad), Courland (Latvia), Saaremaa Island, and the vicinity of Tallinn (Estonia). The second tangible source of agency in the extraregional trade is of Lusatian origin in the SE Baltic. The Lusatian agency is usually distinguished by the pottery found outside their original distribution area, such as in the Mälaren Valley (Jaanusson 1981), and the concentration of metal imports in the Sambian Barrow culture (Luchtanas, Sidrys 1999). Geographically the SE Baltic sits at the crossroads of these two exclusive cultural traditions and provided a economic opportunity for SE Baltic communities

\footnotetext{
${ }^{1}$ The territory includes the areas of the Sambian Barrow culture, Brushed Pottery culture, and Asva group sites that lie in the SE region of the Baltic Sea basin. Geographically, it is separated from the NE Baltic (Finland) by the Gulf of Finland and from the S Baltic by the River Vistula. The SE Baltic region underwent economically similar development in respect to agricultural patterns (Minkevičius et al. 2019), bronze production, and shared cultural elements expressed by a common dominant brushed pottery tradition (Jaanusson 1981) and a lack of an indigenous metalwork tradition (Lang 2007; Čivilyte 2014). The region is culturally distinguished from the advanced Lusatian Culture in the south-west and the Nordic Bronze Age in the west and was more actively integrated into the Pan-European contacts compared to the inland Finland communities in the north.

2 Term 'trade' in this paper is used in a broader sense, not to the economic relations involving markets and money as exemplified in historical accounts, but to supplement the notions of barter and exchange of demanded commodities. In an analysis of bronze production, trade could also account for the organized supply of metal. We use the term intentionally and in line with other usages in the discussion of Bronze Age economic relations (such as Harding 2013; Kienlin et al. 2014; Ling et al. 2014; Earle et al. 2015; Ling et al. 2018).
} 
to further their development and be integrated into wider communication networks. The current consensus in SE Baltic archaeology is that the region had not formed its own local metal tradition and almost all of the artefacts resemble foreign styles (Šturms 1947; Luchtanas, Sidrys 1999; Lang 2007; Čivilyte 2014), most notably Nordic and Lusatian in the Late Bronze Age (c. 1100-500 BC ${ }^{3}$ ). Thus, the most foreign material thitherto for local communities was bronze and everything associated with it can be considered as evidence in attempts to trace the communication of these communities in relations in interregional networks of exchange.

The study of archaeometallurgical collections curated in SE Baltic museums from the early $20^{\text {th }}$ century and a review of all the known sources has provided an opportunity to typologically investigate the casting moulds themselves and to use them to provide an assessment for the intensity of the local bronze production. In the case of predominantly foreign traditions, the study of bronze casting is likewise an investigation into the wider communication networks of the Baltic region. This article aims to deliver a dataset of technical ceramics (the ceramic remains from bronze casting processes) for further research into early metallurgy and an expansion of the discussion of the complex processes of exchange taking place across Northern and Eastern Europe during the Bronze Age.

\section{BRONZE CASTING EVIDENCE IN THE SE BALTIC BRONZE AGE}

\section{Early Bronze Age}

Until recently, the earliest local bronze casting in the SE Baltic was considered to have emerged already in the Early Bronze Age (c. 1700-1100 BC ${ }^{4}$ ) based on several ambiguous isolated cases of technical ceramics and bronze casting moulds. The first indications had been acquired during the excavation of the multihorizon settlement at Lagaža (Latvia). Nine fragments of crucibles were found in a hearth investigated in area A (Лозе 1979). Several fragments of other crucibles were uncovered in the hearth's vicinity. The Lagaža collection could have come from at least 4 different crucibles. However, up until now, it has been unclear whether they are indeed the earliest evidence of local metallurgy as the hearth was found in the periphery of the surviving upper part of the cultural layer. The published ${ }^{14} \mathrm{C}$ dates (TA-749: $3685 \pm 80$, or

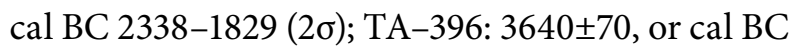

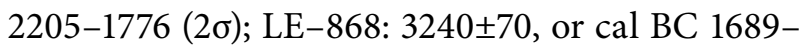
$1323(2 \sigma))$ were acquired by dating wooden samples found in the lower cultural layer of a different area and are therefore of a completely different provenance (Лозе 1979, p. 121). The finds attributed to Bronze Age contexts consist of two settlement periods: one with late Lubāns-type ceramics dated to the Early Bronze Age and a second with brushed pottery possibly overlapping with later Bronze Age contexts. Moreover, the finds had been loosely reconstructed by researchers (Лозе 1979, pp. 79-80, рис. 58), which yielded a crucible with an atypical form that could have not existed at all from a technical perspective. Instead, the most probable types are known Bronze Age crucible forms with the nearest analogies coming from Late Bronze Age hilltop settlements in Latvia and Estonia (Graudonis 1989; Sperling 2014) that postdate the common European crucible forms (Jantzen 2008). Thus, the crucibles found in the Lagaža settlement site could not provide a secure basis for consideration as the earliest appearance of bronze casting in the SE Baltic.

\footnotetext{
${ }^{3}$ Based on the dating of the Northern European Bronze Age (Harding 2000; Vandkilde 2007; Olsen et al. 2011 ; Ling et al. 2014, Čivilytė 2014 with further references).

${ }^{4}$ Based on the same references as note 1.
} 
Second, the Baltic archaeological discourse has for some time considered the stone artefact, which was found in Kretuonas 1C (Lithuania) and was identified as a casting mould (Girininkas 1994, p. 218, Fig. 259; Vasks 2007, p. 66), as one of the earliest pieces of evidence for bronze casting in the region. However, it seems highly unlikely as the depicted negative resembles a bone/antler working tool rather than any known object that is related to metallurgical activities. Furthermore, there is no indication of the type of stone in the original field notes or later publications (Girininkas 1987, p. 66). The find was uncovered during an excavation in a ploughed field and the dating of its context is unclear. The Kretuonas 1 settlement site is multihorizon and the finds date from the Stone Age to the Iron Age (Piličiauskas 2018, p. 88). Most striking, however, is the fact that the artefact in question is not accessible to other researchers as it is not in the Nalšia Museum $^{5}$ (Čivilytė 2014, p. 82). The only reference is a drawing by A. Girininkas (2009, p. 259, Fig. 199) and any assessment of early metallurgy based on the Kretuonas $1 \mathrm{C}$ find lacks a scientific basis as the artefact itself is not available for the investigation and therefore its use as a casting mould is in fact not verifiable via independent secondary studies.

Last, the Dovilai (Lithuania) bronze casting mould $^{6}$ for a Klaipeda-type ${ }^{7}$ axe provided another case that could be superficially seen as evidence of local metallurgy. An axe, which had been found in the same region $^{8}$, was discovered to fit this exact bronze mould (Čivilytè 2014, p. 88). Although the existence of a casting mould and the cast product in the same region has been understood as a strong argument for local production, it is still debatable whether it signals the adoption of metallurgy in local communities or the emergence of a new form of communication and trade with foreign societies. The context of the Dovilai bronze casting mould resembles the common depositional practices as it was found at the bottom of the River Minija with no accompanying finds (Čivilyte 2004 , p. 221). Instead of indicating an established metallurgist's workshop in the region, the data suggest that the earliest possibility for itinerant bronze casting dates to Periods II-III (Čivilytė 2014, p. 39, lent. 1:37) without recurrent patterns in the Early Bronze Age. In all likelihood, it is not by chance that the Dovilai find stood out as the exception in the long research history, indicating that local metallurgy had been a process that was established as a continuous practice later in SE Baltic prehistory.

\section{Late Bronze Age}

In contrast to the Early Bronze Age, finds related to bronze casting in the Late Bronze Age are significantly more abundant. All of them are the remains of cire perdue casting technology and the SE Baltic has been distinguished by the predominant use of clay as a mould material; as a consequence technical ceramics are the main investigated artefact in this article. Tools from other materials such as bronze or stone are sparse. One small bronze chisel is known from the Staldzene (Latvia) hoard (Vasks, Vijups 2004); a second was uncovered during the archaeological investigation of the multi-horizon Brikul,i (Latvia) hilltop settlement (Vasks 1994). One KAM type axe had been reshaped into a socketed

\footnotetext{
${ }^{5}$ During the research presented in this study, V.P. again contacted the Nalšia Museum, which is storing the Kretuonas 1C finds, and, after undertaking an investigation of the find admission acts and museum stores, the chief curator confirmed that no casting mould or anything relatable to bronze working was ever received from Kretuonas $1 \mathrm{C}$ by the museum. Thus, the conditions surrounding the Kretuonas 1C find cast an aura of evidence falsification, although a case of misinterpretation by A. Girininkas is also plausible.

${ }^{6}$ Held at Staatliche Museen zu Berlin - Preussischer Kulturbesitz, Museum für Vor- und Frühgeschichte, inventory no. Ia 3648.

${ }^{7}$ An Armorican or NW Germany-influenced type (Dąbrowski 1968).

${ }^{8}$ Near Šilutė (W Lithuania; held at the Lithuanian National Museum, AR, 107:1).
} 


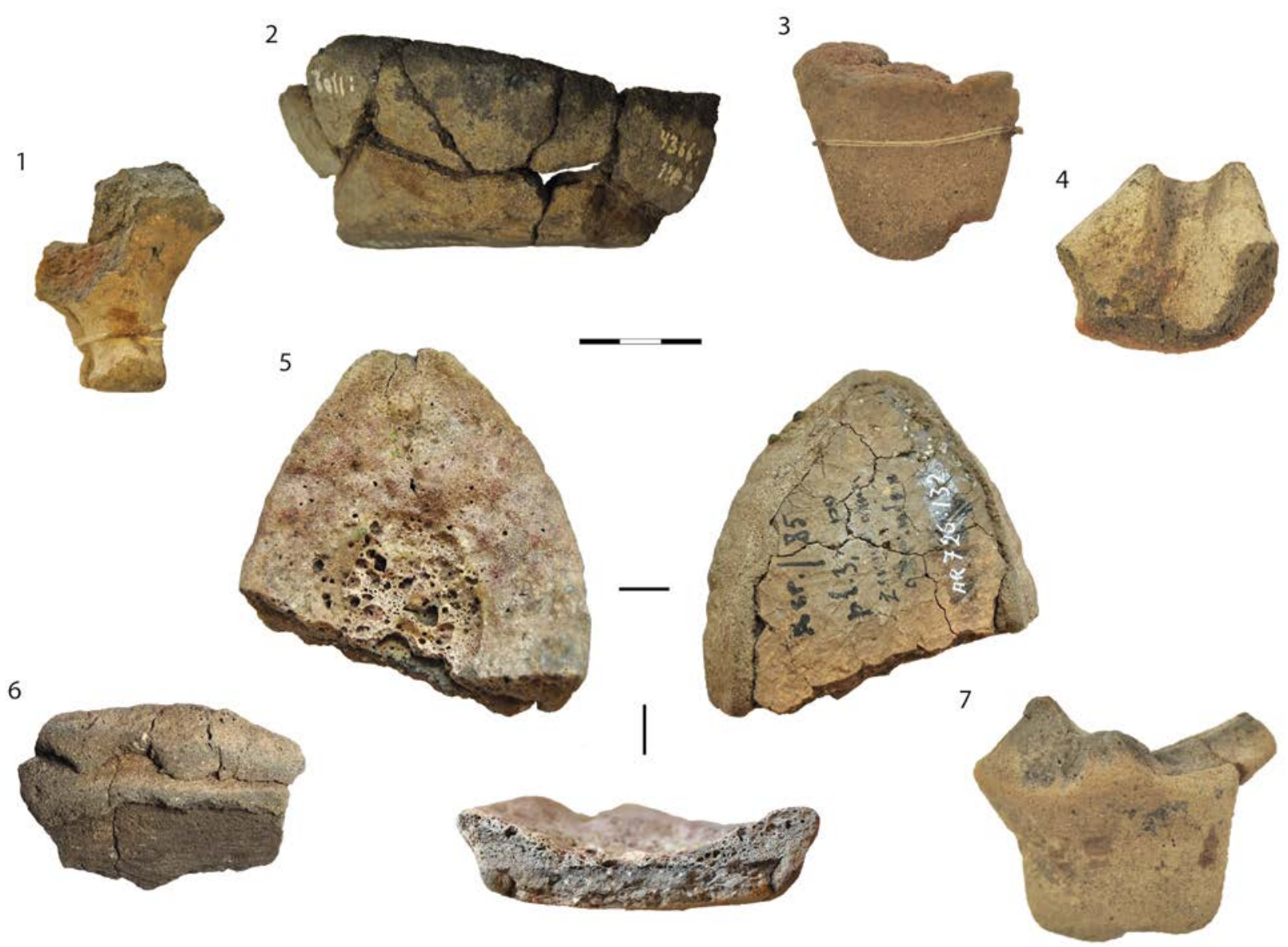

Fig. 1. Crucibles found in SE Baltic hilltop settlements. Localities by number: 1 - Kivutkalns (LNVM, VI120: 982); 2 - Asva (Tallinn university, 4366: 1102); 3 - Kivutkalns (LNVM, VI120: 2103); 4 - Kivutkalns (LNVM, VI120: 829); 5 - Kereliai (LNM, AR 726: 132); 6 - Kereliai (LNM); 7 - Kivutkalns (LNVM, VI120: 1629). Photo by V. Podènas.

chisel (Čivilytè 2014, p. 142, pav. 106), although it differed significantly from the first two in size. Additionally, stone tools found in Late Bronze Age settlements lack a systematic experimental use-wear analysis, making it difficult to distinguish ones used in finishing the bronze products from tools used for other purposes.

This paper presents evidence from 49 sites where bronze casting remains have been found (Appendix 1). The appendix presents data on all the discovered fragments of technical ceramics as no attempt to count the minimum number of casting moulds or crucibles has been carried out. It is nearly impossible to count the latter in large collections, such as at Asva (Estonia), Kivutkalns, Brikuli (Latvia), or Tarławki
(Poland), and the presentation of highly speculative and statistically inaccurate data would in fact impair their interpretation. Most of the bronze casting remains were uncovered in settlement contexts and indicate places of production. The assemblages of Bronze Age technical ceramics are well described in the SE Baltic (Luchtanas 1981; Graudonis 1989; Vasks 1994; Sperling 2014; Čivilytè 2014; Podènas et al. 2016a). Usually these deposits consist of small fragments of casting moulds for ring-shaped artefacts, i.e. armbands, neck rings, or ingots, and less frequently thermally affected crucibles with other finds attributed to the collections. The crucible finds (Fig. 1) constitute the second most numerous find category in the assemblages. 439 crucible fragments 


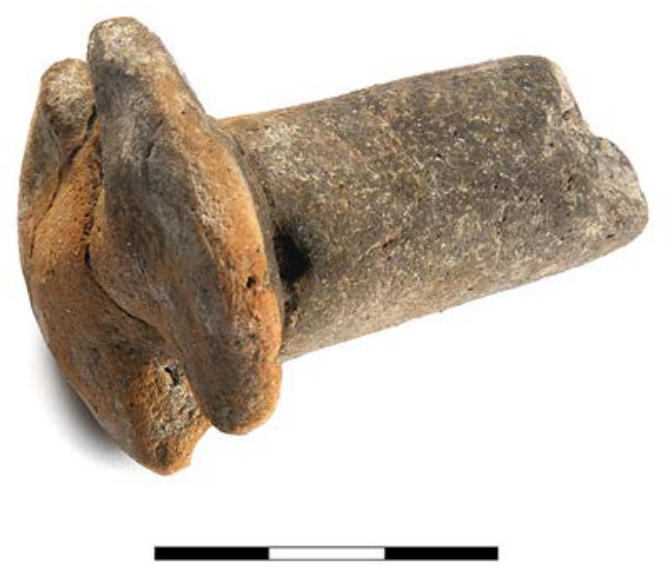

Fig. 2. A clay plug for a double-sided casting mould, found in Kivutkalns (LNVM, VI120:254). Photo by LNVM.

Fig. 3. Clay casting moulds for ring-shaped artefacts. Localities by number: 1 - Sokiškiai (LNM, AR 211: 529); 2 - Brikuḷi (LNVM, A.12379: 450); 3 - Velykuškès (VDKM, 887: 237); 4 - Narkūnai (LNM, AR 594: 470; 492; 497; 754). Photo by V. Podenas. have been found at 21 sites, concentrated mostly in 2 settlements (Kivutkalns, Brikulii). Occasional finds include double-sided casting moulds for axes or spearheads; less frequently casting moulds were distinguished as being specifically for ornaments (Sperling 2014, p. 439, Taf. 10:2,3). The rarest find has been a clay plug for a double-sided casting mould, only one of which is known, the one from Kivutkalns (Fig. 2).

Almost omnipresent in the technical ceramic collections for bronze work in this period are the fragments of casting moulds for ring-shaped bronzes (Fig. 3). It is difficult to distinguish them as a specific type because none of them has a distinguishable end that could help identify the cast object. Researchers suggest that possibly armbands, neck rings, or ingots were cast in these ring-shaped moulds (Čivilytė 2014; Sperling 2014; Podènas et al. 2016a). These are typologically likely to date to Periods IV-VI; a more precise chronology could be established only through the more active dating of their context.

\section{4}

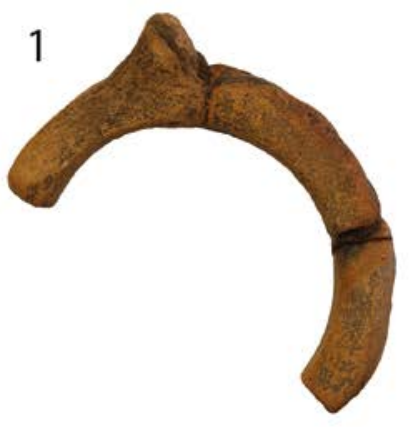

\section{3}
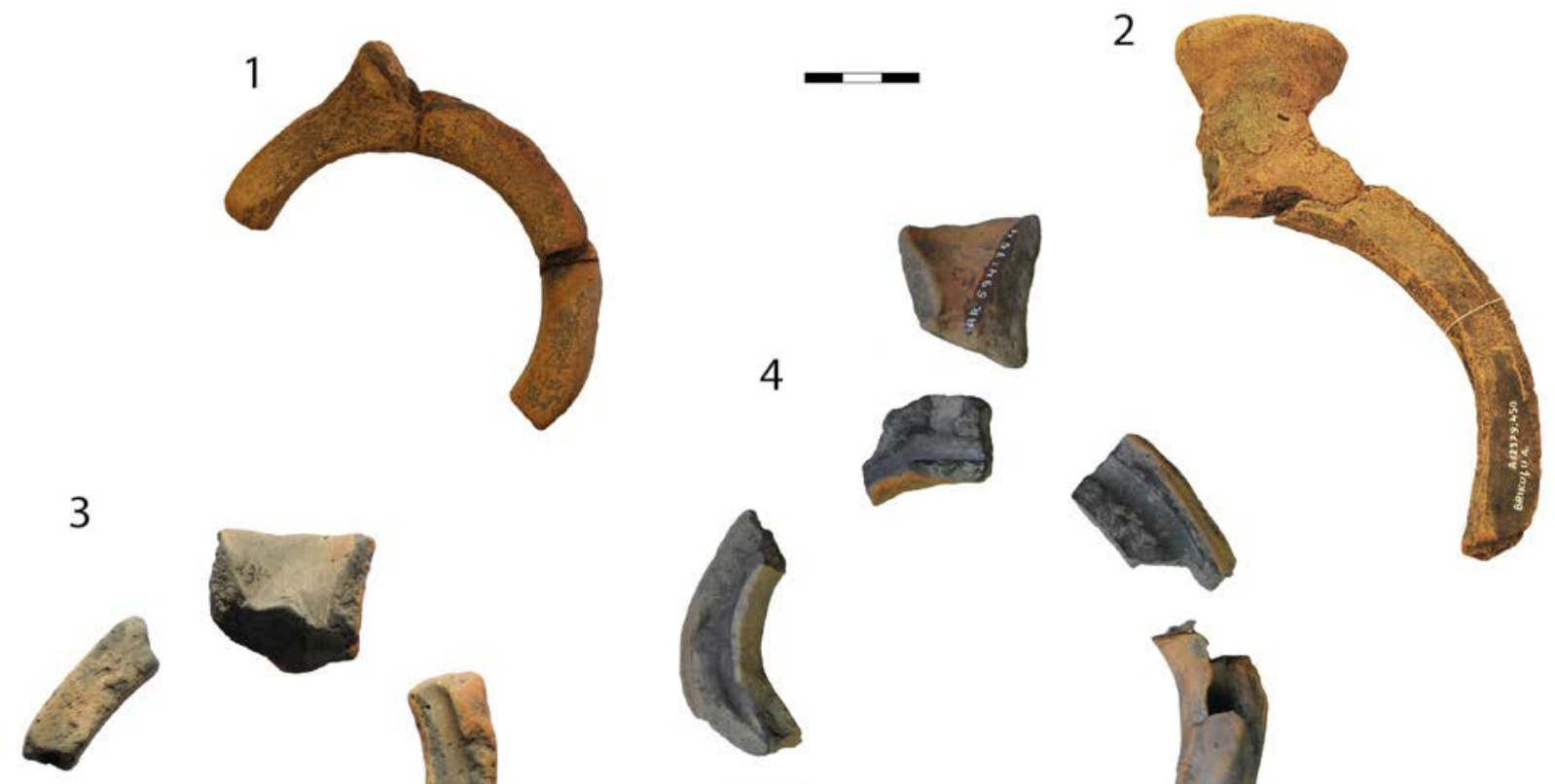
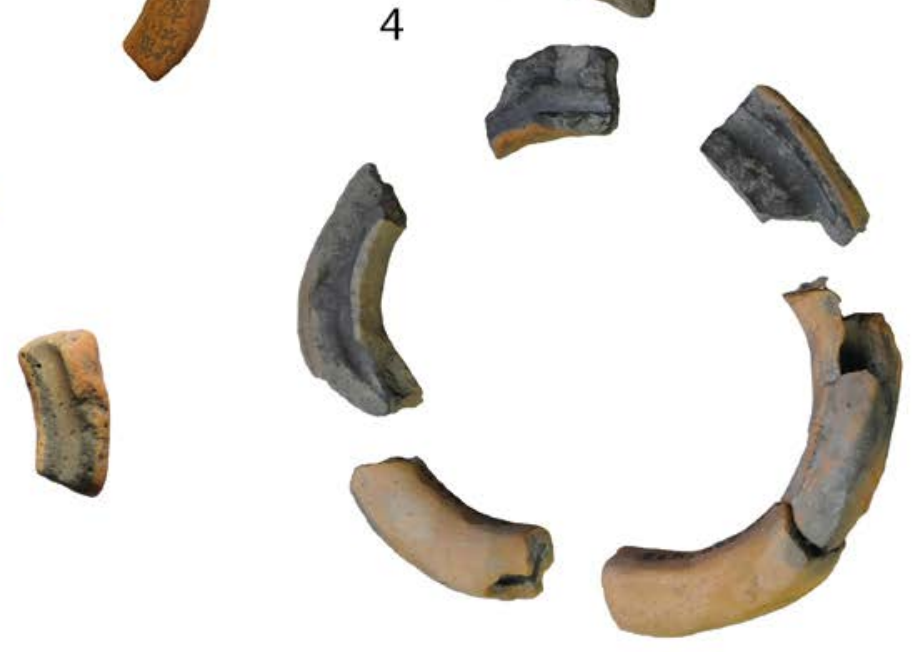
1

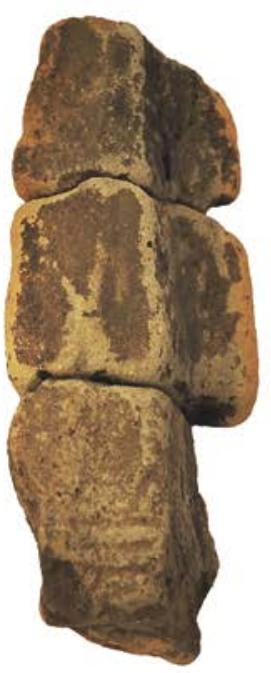

3

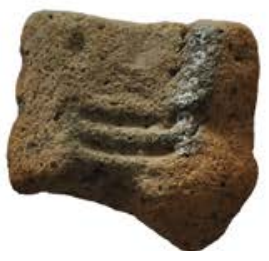

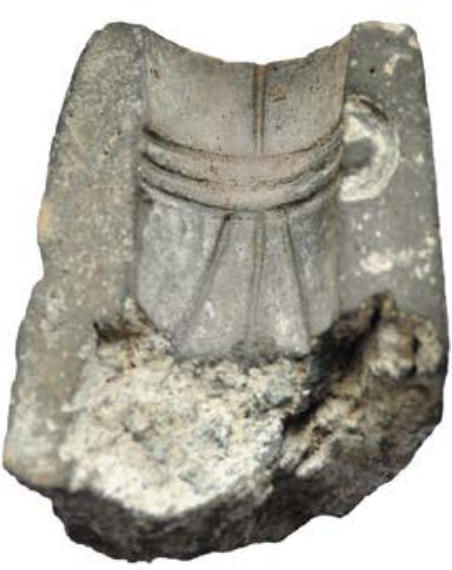

5

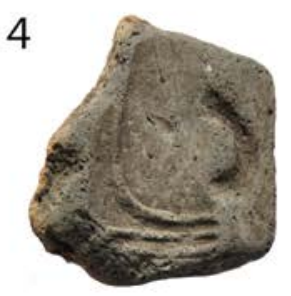

2

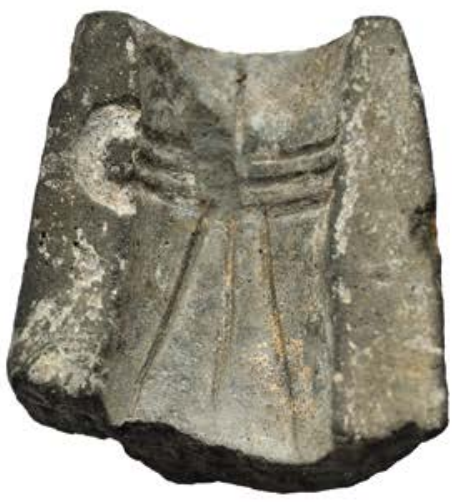

6

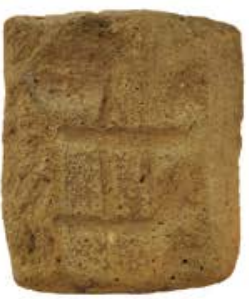

Fig. 4. Clay casting moulds for KAM axes, found in: 1 - Brikul̦i (LNVM, A.12405: 111; 282); 2 - Narkūnai (LNM, AR 594: 495); 3 - Baltkāji (LNVM, V.9082: 2); 4 - Vosgèliai (VDKM, 1378: 10); 5 - Ķivutkalns (LNVM, VI120: 1244); 6 - Ķivutkalns (LNVM, VI120: 203). Photo by V. Podenas.

The consumption of bronze ornaments has not been documented to a comparable extent and the importance of casting moulds for ring-shaped artefacts in the SE Baltic (cf. Luchtanas, Sidrys 1999, 2 priedas vs. Appendix 1) must be attributed to another reason, the likeliest being a wire ingot interpretation. Enormous amounts of ring-shaped casting moulds (Appendix 1) have been discovered in extensively excavated settlements with better preserved Bronze Age horizons. The most numerous and presumably the most productive find spots judging by the number of fragments are the Asva, Kivutkalns, Brikuli and Tarławki hilltop settlements (Appendix 1). However, please note, while it might have been the most frequently cast object in the SE Baltic, it is easy to overestimate its significance by the fragment count. Casting moulds were often broken to small pieces in the process of removing the cast object from the mould. Moreover, many fragments could have been the remains of a failed casting. The fragmentation rates for these kinds of moulds are significantly higher than for double-sided clay casting moulds. Casting moulds for other objects and crucibles provide a stronger argument for a discussion of the extent of bronze casting at the production sites.

Mostly double-sided casting moulds for socketed axes were identified for a particular type. Out of 110 fragments of casting moulds for axes, roughly 48 (43.64 \%) carried distinguishable negatives. Most of them (44) consisted of three grooves or the appearance of other distinct decorations (Fig. 4) that are typical to KAM axes. These axes were cast on the peripheries of the Nordic Bronze Age world (Melheim 2015) as well as in the vast area between Scandinavia and the 


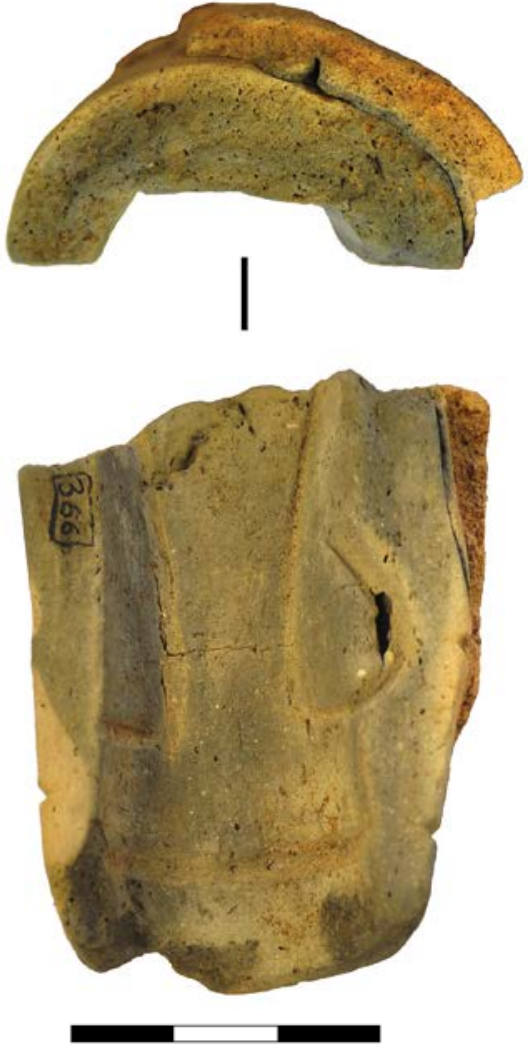

Fig. 5. A clay casting mould for an axe of a similar type to the Kalinówka Kościelna hoard axes. Found in Dievukalns (LNVM, V.217: 366). Photo by V. Podenas.

Volga-Kama region. KAM axes are typologically dated to Periods IV-VI. Direct dating of the wooden handle remains from the Astangu (Estonia) bronze axe (Paavel et al. 2019, p. 5, table 1) established a particularly late date of Poz-82895: $2345 \pm 30$ BP, or cal BC 510-371 $(2 \sigma)$. One exception from the identified casting moulds for axes, i.e. a type not strictly attributed to a specific region was found in the Dievukalns (Latvia) hilltop settlement (Fig. 5). It had a handle in the middle of the axe, one groove surrounding the axe's mouth, and additional $\mathrm{L}$ shaped grooves running down the corners of axe's blades. The negative in the mould is similar to axes from the Kalinówka Kościelna
(Poland) hoard (Gimbutas 1965, p. 437, Fig. 295:4), but the loop was formed further away from socket than was usual. An axe casting mould similar to that from Dievukalns, but significantly smaller, was found during the archaeological investigation of Sokiškiai (Lithuania) hilltop settlement (Grigalavičienè 1986, p. 120, pav. 24:1). Typologically these axes date to Period VI.

Many of the clay casting moulds for axes were found in Kivutkalns and Narkūnai (Lithuania) hilltop settlements (Appendix 1). Other localities had several fragments per site. Casting moulds for spearheads and ornaments are sparse in the SE Baltic. Moulds for both types of artefacts have been found in Asva, whereas the Mūkukalns and Brikul̦i (Latvia) excavations yielded 1 and 9 spearhead casting mould fragments respectively, (Fig. 6) without any signs of bronze ornament work (ibid.). The only pin casting mould, which was found in Asva, was attributed to the Härnevi-type and dated to Period V-VI (Sperling 2014, p. 148). The spearhead casting moulds from Asva and Brikul,i are for undecorated objects, which are typical for the entire Late Bronze Age, Periods IV-VI, whereas the Mūkukalns casting mould has decorations resembling those of Pfahlbau-type spearheads, which date to Periods V-VI (Baudou 1960, p. 14, tafel III:IVC).

Based on analogies in the spatial distribution of bronze casting debris such as at Biskupin ${ }^{9}$ or Sobiejuchy (Poland; Niesiołowska-Wędzka 1991, p. 65; Harding et al. 2004, pp. 197-198), it should be possible to locate the workshop of an established bronze caster in the SE Baltic settlements. However, this does not mean that bronze casting itself was carried out in the habitation zones, since Jockenhövel (1986) and A. Harding et al. (2004, p. 198) note that it is unlikely that casting in furnaces took place

\footnotetext{
9 The interpretation of spatial analyses is considered to be at risk of oversimplification in an attempt to explain the intrasite distribution patterns. Harding et al. (2004) doubt the 6 areas of metallurgy distinguished by Niesiołowska-Wędzka (1991) and point out that data presented in original articles (Pieczyński 1950; Szafrański 1950 cited in Harding et al. 2004) could account for 23 areas in Biskupin, several of which are located in streets.
} 


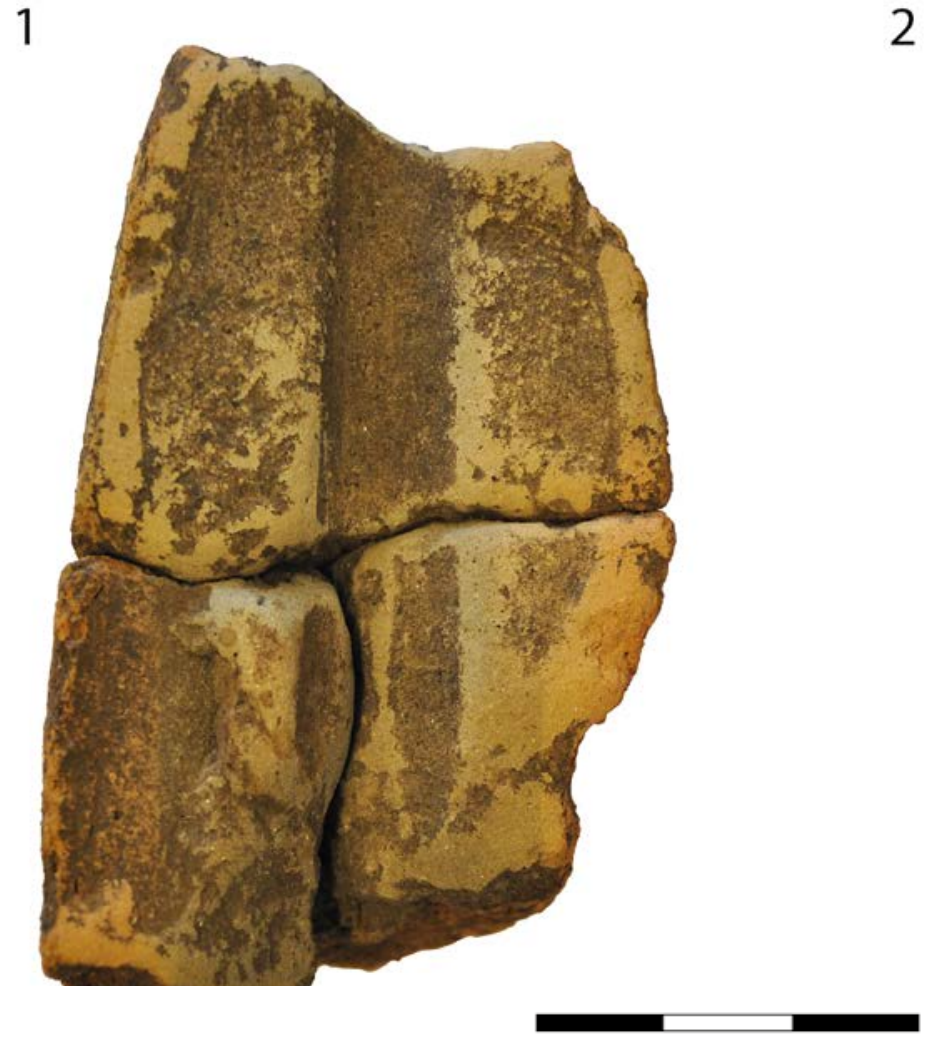

Fig. 6. Clay casting moulds for spearheads. Localities by number: 1 - Brikuḷi (LNVM, A.12379: 11, 275, 283); 2 - Mūkukalns (LNVM, A.11848: 1041). Photo by V. Podenas.

inside houses even at the Late Bronze Age sites in $S$ Germany or the Early Iron Age sites in Central Poland. Comparable material for bronze workshops is known from the Feudvar (Serbia) settlement, which has already been discussed in SE Baltic archaeological literature (Čivilytė 2014, pp. 126-127; Podènas et al. 2016a, pp. 168-169), however the current knowledge about production sites suggests that no dedicated workshop was necessarily used as shown by the bronze crafting found inside longhouses investigated in SE Sweden as well as in secluded parts of the sites (Sörman 2017). The likeliest explanation for casting debris inside houses or near them is that it was brought there for finishing. Nonetheless, SE Baltic Late Bronze Age settlements had not reached the size of the Lusatian strongholds and while one side of a hill was inhabited, the other may have been used for production. Moreover, bronze crafting debris is better understood as spatially varied crafting loci (ibid), divided between places of mould making, casting, metal finishing (polishing, edge hardening), and completion (hafting, hilting, and strapping). Furthermore, it is difficult to distinguish a workshop as most settlements lack technical ceramic finds or underwent post-depositional processes such as ploughing which disturbed the original stratigraphic profiles, jumbling up and scattering the bronze casting debris (Podènas et al. 2016b). This is a significant problem for hilltop settlements which typically lack chronologically closed, single period horizons and were usually resettled later in prehistory. Thus, the spatiality coherent patterns of technical ceramics are generally sparsely attributed to a particular household. There are available data from only several widely excavated sites (Vasks 2007; Sperling 2014; Podènas et al. 2016b) to proceed with a spatial analysis in 


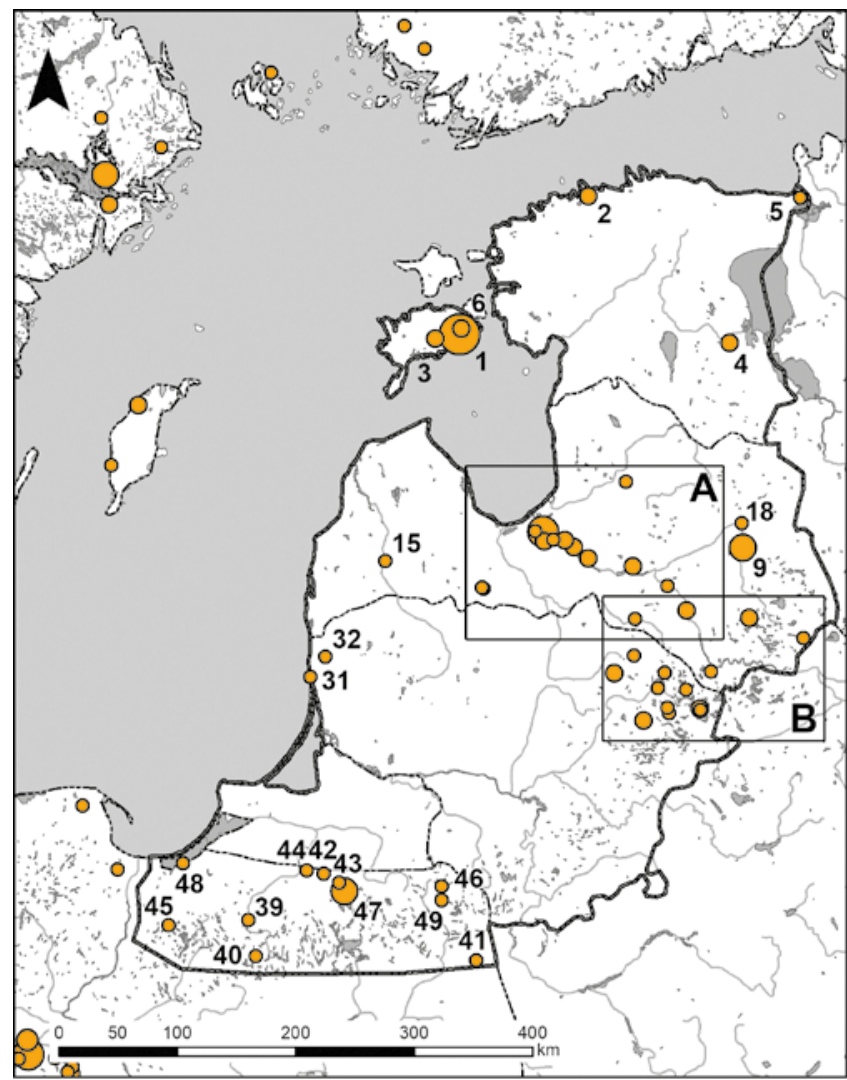

Amount of refractories in findspots, by piece

- 1-10 ○ 11-100 $\bigcirc 101-300$

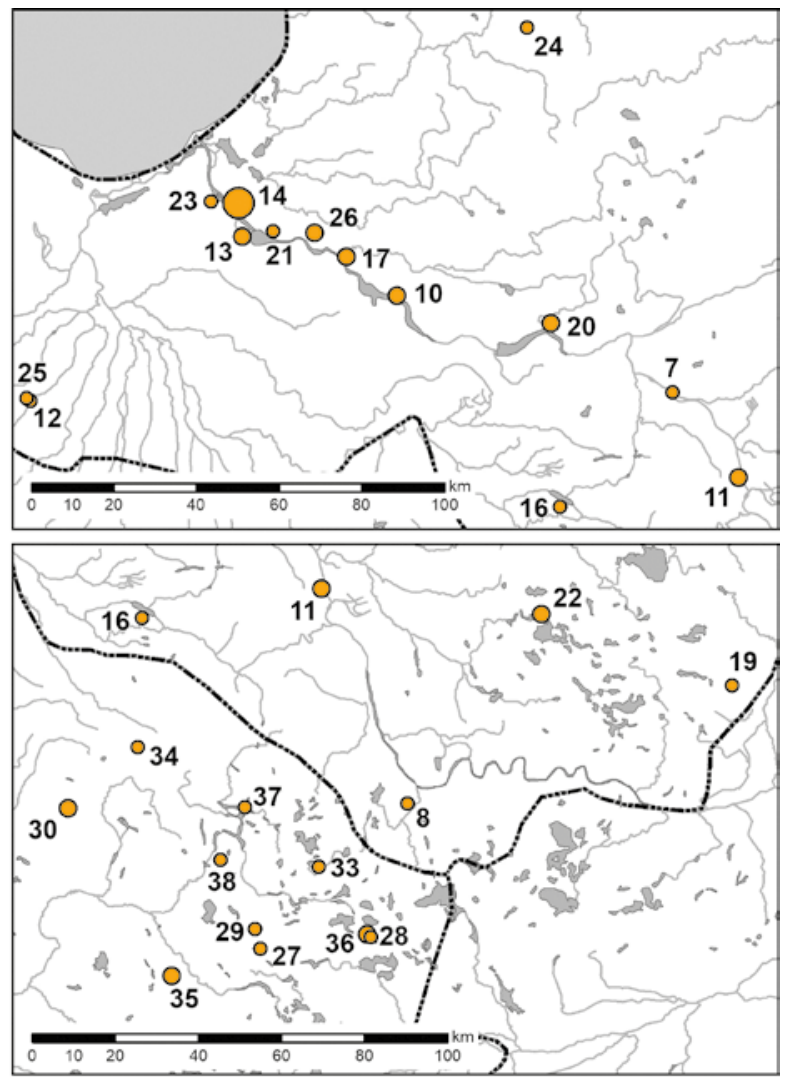

$801-1200$

$1201-1500$

Fig. 7. The locations of the bronze production sites based on the collections of technical ceramics in the SE Baltic Bronze Age. The numeration corresponds to Appendix 1. Drawing by V. Podenas.

an attempt to study possible workshop areas in the region's settlements. Bronze casting debris in Asva was distributed throughout the hilltop settlement although particular concentrations were documented on its NE side where a distinguishable hearth construction was found and considered to have been used by metallurgists (Sperling 2014). Other areas of crafting loci in Asva include higher concentrations in the centre of habitation area (ibid). Refractories related to bronze casting at Kivutkalns lay mostly in the vicinity of the enclosures and coincided with the building sites as well (Vasks 2007). The Bronze Age technical ceramics discovered at Narkūnai were distributed in the N and SW areas and separated from each other in the hilltop settlement's habitation area (Podènas et al. 2016b). A former area coincided with a nearby area of postholes, which were attributed to the two northernmost buildings in the investigated area because most of the discussed finds lay between them in the enclosure ( $c f$. Čivilyte 2014, p. 123, pav. 100). The latter cluster was widespread and was mostly discovered within the enclosure; it, therefore, might point to places where the casting moulds were later worked and swept away from the habitation zone, creating secondary refuse deposits.

Cast objects in SE Baltic are difficult to attribute to a specific type and casting moulds with representative negatives have been found at only 13 sites. Most of the identified casting moulds were used for KAM socketed axes, one or two for Kalinówka Kościelnatype axes, one for a Pfahlbau-type spearhead, and one for a Härnevi-type pin. Three of the four identified 
types have been attributed to Scandinavian influence and the rest have stylistics similar to metalwork from both the Scandinavian and the Lusatian regions. No atypical or considerably local types appear in the Bronze Age SE Baltic casting moulds. Thus, it is important to discuss the way Scandinavia influenced SE Baltic metallurgy and discuss the possible regions of influence.

\section{Site patterns}

49 known sites in the region have a peculiar distribution with a clear geographic favouritism towards territories in the SE Baltic coastal area, the vicinity of the River Daugava, the NE Lithuanian and SE Latvian uplands, and the Masurian Lakeland (Fig. 7). Most of the finds have been collected in hilltop settlements (Fig. 8) with only occasional appearances at other types of sites. Only two finds were found inside the mounds of the Rèznes (Latvia) and Jełgun (Poland) barrows and these are more likely indicative of chance finds than a positive association with ritual burial practices. A possible explanation is the foreign nature of the technical ceramics and their inability of being employed for any secondary use. As most of the clay casting moulds had been broken into small pieces, they were viewed as production waste and were usually discarded.

In assessing the 3339 finds from the region, 2761 (82.69 \%) were collected in only four extensively excavated sites (Asva, Ķivutkalns, Brikul̦i, and Tarławki). These hilltop settlements had been situated in different, economically important areas and were therefore exceptional because of the site's role in the communication networks. These collections do not represent the typically expected view of metallurgical assemblages at most sites. Other extensively excavated hilltop settlements like Narkūnai, Sokiškiai, Kereliai (Lithuania), Asote, Dignāja, Vīnakalns (Latvia), or Iru (Estonia) have not yielded such enormous assemblages, but rather

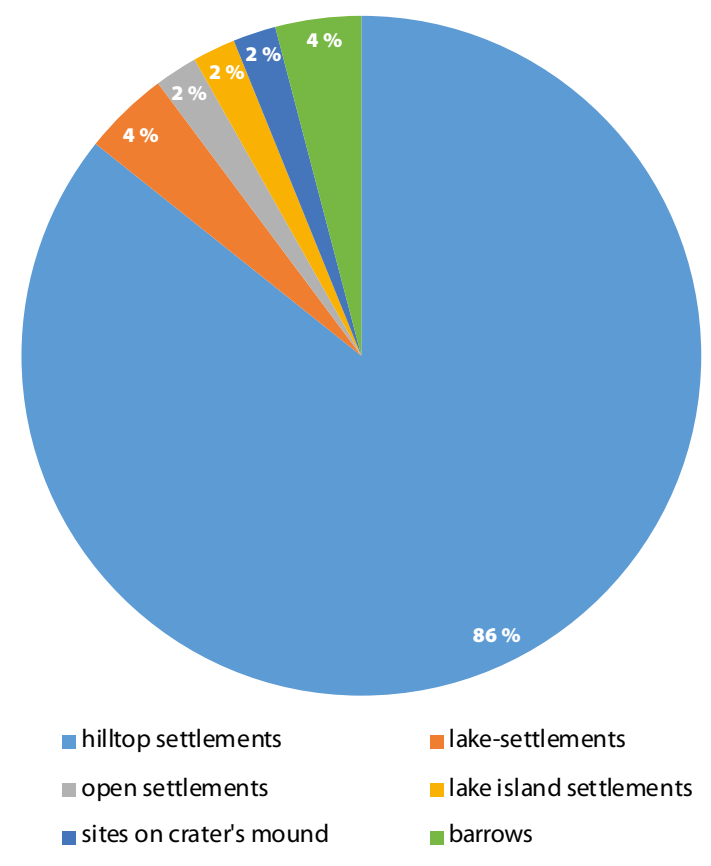

Fig. 8. The types of sites where technical ceramics were found. Graph by V. Podenas.

small collections representing short-term activities. Little reason for the limited quantities of refractories at these sites could be attributed to the formation processes these sites underwent later (Podènas et al. 2016 b) or a lack of knowledge by the investigators in identifying refractories (Kujpers 2008). In the long research history of the SE Baltic Bronze Age metallurgy (Šnore 1936, p. 65, att. 7; Meinander 1954, pp. 44-49, abb. 27, 30-34, Tafel 30:k; Дайга 1960; Lõugas 1966; Luchtanas 1981; Waluś 1982; Kuz'minych 1996; Luchtanas, Sidrys 1999; Čivilytė 2004; Čivilytè, Mödlinger 2010; Vasks 2010; Čivilytè 2014; Sperling 2014; Podènas et al. 2016a; 2016b; Podènas, Babenskas 2017), patterns of long-term activities would have been noticed and the situation indicates a rather more likely scenario of different recurrent occasions of bronze castings at different sites. Thus, settled bronze casters or workshops are likely to have existed at only four sites, but this may also represent the importance of these sites in trading networks and facilities for visiting smiths. 
Asva on the Baltic Sea coast of Saaremaa Island has yielded the most refractories with associated casting moulds for KAM axes and Härnevi-type pins (Appendix 1). Technical ceramic assemblages were also found at other sites on the same island such as at Ridala and Kaali (Estonia). Other Nordic-influenced occurrences besides technical ceramics include the Tehumardi (Estonia) hoard (Sperling 2013) and the Lülle (Estonia) stone ship burial (Lang 2007) in S Saaremaa, roughly 50-75 km from Asva. The Asva assemblage is also distinguished from most of the SE Baltic sites by the significant amount of fine-grain pottery recovered, which has possible technological origins in the Scandinavian or Lusatian regions (ibid, p. 126); it therefore seems that Asva worked as a strategically situated workshop (Sperling 2014; Earle et al. 2015) and as a trading ground for circum-Baltic Sea travellers. The most likely model would be a free trade port (Polanyi 1963) like in economic relations in stateless societies.

Comparable sites where this economic model likely existed are usually located in coastal zones. They are characterized by considerable evidence of bronze working and the artefacts recovered there suggest direct links with a very wide area, including an unusual proportion of imports in some cases; the existence of this kind of site has been discussed for both Scandinavian and British cases (Bradley 1985; Melheim et al. 2016). The locations for these production sites seem to have been carefully selected and may have served as neutral places where balanced transactions could take place (Bradley 1985, p. 699). The dominant brushed and smooth pottery indicates that the local SE styles were in the household material culture and show that Asva was likely established by locals or hybridized community. The rough pottery inherent to overseas and SE Baltic manufacturing traditions is found at a significantly lower frequency compared to the local wares (Jaanusson 1981, p. 51, table 9). Thus, Asva emerged in reaction to visiting circum-Baltic travellers attempting to establish contacts with local traders or may have even served as a mixed settlement community.

Kivutkalns is the second most important known base for the trade and production of bronze in the East Baltic and is situated roughly $175 \mathrm{~km}$ from Asva, in the lower Daugava river area. Besides the technical ceramics (Fig. 9), Nordic and Lusatian influences are tangible, but significantly smaller compared to those from Asva. Even though similar fine-grained Asvan pottery is apparent in Kivutkalns, it is sparse and much of the pottery assemblage is items like household ceramics at inland hilltop settlements, thus it represents more of the local SE Baltic traditions and communities. The vicinity of the lower Daugava river is lacking stone ship burials and thus a basis for identifying the existence of a Scandinavian population in the immediate area. These ship settings are, however, apparent in Courland, roughly 125$175 \mathrm{~km}$ to the west. There the archaeological discovery of the Staldzene hoard (Vasks, Vijups 2004) and the cluster of stone ship burials at Lỉbe, Mušinas, Bīlavi, Birznieki, Lielrenda, Paušas, Plintiņi, and Pojas (Latvia) (Граудонис 1967, pp. 68-73) have provided additional arguments to hypothesize the existence of a nearby Nordic settlement ${ }^{10}$ in the SE Baltic that had actively participated in communication and barter with the indigenous people.

Hilltop settlements situated in the vicinity of the mid-Daugava and the SE Latvian and NE Lithuanian uplands have contributed abundant cases to the study of bronze casting in the SE Baltic Bronze Age (Fig. 7). These assemblages are usually represented by several casting moulds per site, the only exceptions having been recovered from the Brikuḷi and Narkūnai hilltop settlements established in the northern and southern peripheries of the cluster. Third in overall collection size in respect to the number of technical ceramic

\footnotetext{
${ }^{10}$ However, the settlement is yet to be discovered.
} 
2
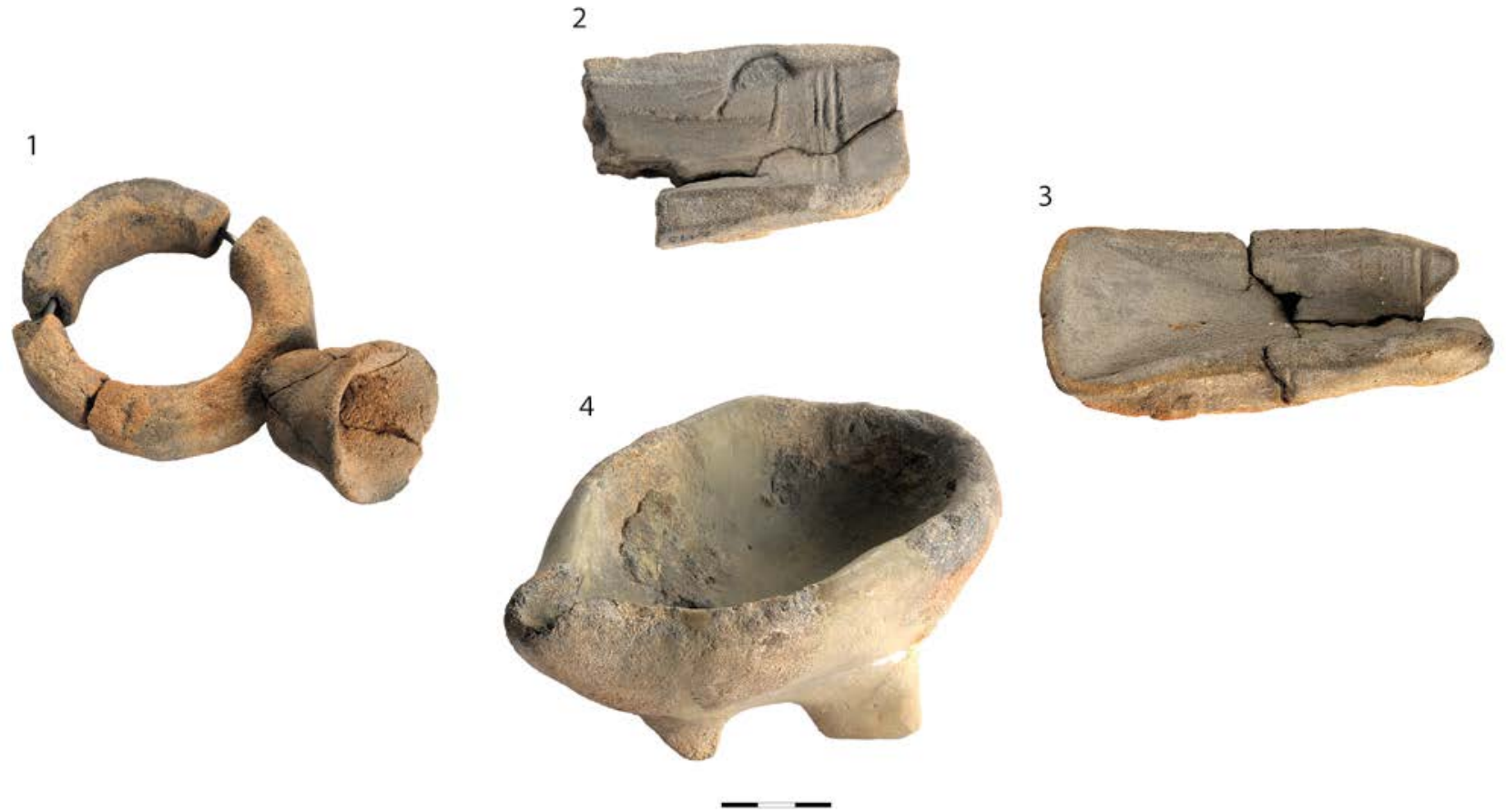

Fig. 9. The most representative collection of technical ceramics has been found at Ķivutkalns hilltop settlement. 1 - a casting mould for a ring shaped artefact (LNVM, VI:120: 2392; 2406); 2, 3 - casting moulds for a KAM type axe (LNVM, VI120: 2115; 1498); 4 - a crucible (LNVM, VI120: 1449). Photo by LNVM.

fragments recovered in the SE Baltic is Brikul,i, which is situated on the east shore of Lake Lubāns, far inland in Latvia. Current knowledge suggests that this region was traditionally associated with extra-regional communication networks during the Subneolithic (Vasks 2010). The significant number of crucibles in the settlement makes an argument possible for actively recurrent metallurgy practices there. The identifiable casting moulds are for spearheads, KAM axes, and the rest of double sided casting moulds were likely made for production of axes. Casting moulds for ringshaped artefacts are numerous as well. Comparably to Brikul,i but occupying a less significant place in this bronze casting communication network was the Narkūnai hilltop settlement. The site's assemblage is distinguished by more frequent than usual casting moulds for KAM axes and less frequent ring-shaped artefacts (Appendix 1).

Of the studied bronze production distribution areas in the region, the Masurian Lakeland had been nearest to contact with Lusatian culture, however, only a single site (Tarławki) is known with a higher number of finds associated with bronze casting. The more indicative finds from Tarławki favour a Nordic influence instead of Lusatian one as several casting moulds attributable to KAM axes were discovered alongside casting moulds for ring-shaped artefacts. The investigations at the ten remaining localities have yielded only several fragments of clay casting moulds for ring-shaped artefacts. Information on stone ship burials in the region is sparse but occurs in the literature for the Kaliningrad District (Okulicz 1976). Judging by the number of refractories and technical fragments, the most significant region seems to have been the coastal area, which includes the two sites with the largest assemblages, those at Asva and Kivutkalns. The coastal zone had influence inland in proportion to the extent to which it was connected with river routes, such as with the Daugava. A concentration of sites with the remains of metallurgical activity ran in the 
lower River Daugava a further $100 \mathrm{~km}$ inland beside the Daugava before spreading northwards to Lake Lubāns and the hilltop settlements established in the Baltic Uplands in NE Lithuania and SE Latvia. These sites are numerous, but only Brikul̦i and Narkūnai stand out with greater assemblages of refractories and associated technical ceramics, the other sites yielding only sparse collections of technical ceramics. Other cases connecting further inland settlement networks, for example, the hilltop settlements at Kõivuküla (Estonia) and Sārumkalns (Latvia), are sparse, but were likely established for their economic connections with other communities further inland. The separate cluster formed in the Masurian Lakeland seems less important compared to the more numerous sites that formed in the northern areas. Nonetheless, the Masurian Lakeland area seems to have formed its own economic network area, which was not directly connected with established network around the River Daugava and a significant territory of roughly $200 \mathrm{~km}$ between the two zones was left without any bronze production (Fig. 7) during the SE Baltic Bronze Age. This territory also lacks hilltop settlements and was probably employed only between the neighbouring communities in unenclosed settlements without exploring barter possibilities with foreign travellers.

\section{Assessment}

The review of all the analysed sources of bronze casting in the SE Baltic has presented several conflicts of interpretation for the question of whether the early bronze casters were locals or foreigners. First, the process of the active recurrence of bronze casting in the region appears only during the Late Bronze Age. The Early Bronze Age lacks evidence for bronze casting and the Dovilai bronze casting mould stands alone as an ambiguous source. Therefore, it is not surprising at all that metal consumption in the SE Baltic was sparse. Only after the appearance of locally executed metal casting did metal consumption roughly double (Luchtanas, Sidrys 1999). Until then it is safe to postulate that the region depended on imports exclusively. The bronze consumption and metallurgical studies (ibid; Čivilytė 2014) have highlighted that later during the Early Iron Age (500 BC - ad 0) recurrent bronze casting had stopped and regressed from a metal culture for half of millennium instead of instantly progressing to iron. Second, despite numerous localities and assemblages, no local forms or decorations of bronze items were established in the production of SE Baltic metalwork. Bronze casting production waste predominantly favours the influence of the Nordic region as evidenced by casting moulds for KAM axes and Härnevi-type pins. Third, large discrepancies in the assemblages are apparent for the different fragmentation rates of double-sided casting moulds for actual products and casting moulds for ring-shaped artefacts, likely ingots to use up metal leftover after production. This would be one of the likely explanations for the abundance of ring-shaped casting moulds in a region that had not valued bronze ornaments over axes or weapons. Thus, the emergence of bronze production in the SE Baltic was not developed locally and direct trade in locally cast metal had likely occupied a temporal, but significant role in the local economies.

Bronze production at the SE Baltic settlements suggests the existence of different types of communication and trade, especially when comparing the inland areas with coastal sites. The hilltop settlements in Asva and Kivutkalns could have been established not only as strategically situated workshops but also ports of trade (Polanyi 1963) like neutral trading areas in a stateless society. These sites likely represented two or three different interacting cultures of Nordic, Lusatian, and SE Baltic origins, where secure grounds were provided for production that lasted for a couple of weeks at the least (Luchtanas et al. 2019). Moreover, these grounds were used for either an immediate exchange or preparation for an exchange further inland. To a lesser degree, grounds within the 
Brikul, enclosed settlement could have been employed similarly as were those in other enclosed settlements further inland. Another possible explanation for occurrences of bronze casting represents a different type of interaction as well, i.e. the likely short-term stay of a specialist, together with an accompanying security party, at the settlement to cast the products according to local demand in exchange for the demands of the visitors. The arguments for mobile craftsmen lie in the high value of the metal in the region at the time and the near certainty that the specialist had originated outside of the SE Baltic.

\section{PLACES OF PRODUCTION AS A SCENE FOR COMMUNICATION}

Bronze production sites in the SE Baltic have started a discussion with different levels of interaction occurring in relation to bronze production and exchange. The communication represented by the foreign artefact forms demonstrates at least three levels of communication networks: intraregional SE Baltic; circum-Baltic, and interregional between the W Baltic to the mid-Volga-Kama basin. The interaction models range from long-distance travel by small groups of people to mediator-based communication. The notion of intermittent movement (Vandkilde et al. 2015) reflects a possible way, in which visitors introduced the cultural information of bronze casting while adapting to the local social environment. Of equal importance were the adaptations by local SE Baltic communities, which allowed them to participate in reciprocal communication, introducing initially incomprehensible symbols of a strange world (as defined by Neustupný 1998, p. 19) into their own culture.

\section{Intraregional communication networks}

Intraregional SE Baltic communication networks links the possible established Scandinavian settlements (Šturms 1947) to hilltop settlements and further afield to unenclosed settlements. Arguments for the appearance of groups of Nordic people come in the form of burials in their style as expressed by stone ship burials and hoards in the vicinity of coastal Courland, Saaremaa Island, N Estonia, and the Sambian Peninsula. The presumed links between these burial grounds to enclosed settlements could explain the largest assemblages of refractories at the Asva, Kivutkalns, and, to a lesser degree, Tarławki hilltop settlements. A further exchange between enclosed settlements could have occurred through the use of locally known routes to possible barter locations. In addition, the exchange inside the enclosed settlement network provided better security for the accumulation of bronze items and tradable stock. Finally, further communication between enclosed and unenclosed settlements would have continued in the SE Baltic for a while longer and did not include the activities of bronze casting, but likely included the cast products of bronze manufacture.

The intraregional dimension of interactions related to bronze casting and the exchange of products is better exemplified by cases further inland as the coastal sites were possibly more actively influenced by the circum-Baltic networks (Wehlin 2013, p. 185, Fig. 9.2). A better-studied context at the Narkūnai hilltop settlement has provided an instance of the largest collection of casting moulds for KAM type axes, but not much else. Its spatial analysis (Podènas et al. 2016b, p. 220, Fig. 21) indicates two separate manufacture areas on the $\mathrm{N}$ and $\mathrm{S}$ sides of the hilltop settlement while most of the production waste was swept out into the enclosure area outside the residential zone. The presumed explanation for separate areas of bronze casting is the establishment of short-term hearths which were later destroyed. The most identifiable cast object was axes, which could have served as one of the more exchanged objects in other hilltop settlements. The already discussed site pattern overlaps the region of enclosed settlements 
in the SE Baltic (Podenas, forthcoming), which is a fact indicative of an active market amongst these communities in contrast to those living in unenclosed settlements.

The context of the sites integrated into both the intraregional and the circum-Baltic communication networks significantly differed from the sites further inland. Based on the excavation accounts from the Kivutkalns hilltop settlement, A. Vasks (2007) indicated a significant discrepancy in the technical ceramic spatial distribution between the lower and upper horizons. In the lowest stratum, the casting moulds and crucibles were concentrated in a $5 \mathrm{~m}$ wide zone near the enclosure, whereas the finds from upper horizons were dispersed all over the hilltop settlement with the largest concentrations found in the vicinity of buildings. That bronze casting was conducted in a residential area was inferred after a spatial analysis of the refractories by U. Sperling (2014). He distinguished several bronze casting zones among the houses in the Asva hilltop settlement. However, it is worth noting that the bronze casting waste was found dispersed throughout the habitation area. In the hilltop's NE area (Asva E), a fragment of a casting mould for a KAM-type axe (ibid, taf. 7:1) was found near a hearth that was supposedly used by metallurgists. The excavation in the settlement's C-SE area (Asva F) yielded a casting mould for a Härnevi-type pin (ibid, taf. 10:2, 3), a piece unique to the SE Baltic technical ceramic assemblage. Thus, more recurrent bronze casting in the coastal sites could have left the waste more widespread in the settlement area.

\section{Circum-Baltic Communication Networks}

The coastal Baltic communities were more familiar with the culture that brought metal and active contacts within the circum-Baltic level as is evidenced by the more frequent appearance of early rusticated pottery at bronze production sites. The archaeological context of the enclosed settlements in the SE Baltic lacks evidence of aggressive attacks and indicates only quick abandonment in several cases (Graudonis 1989; Sperling, Luik 2010; Podènas et al. 2016b); therefore, the possible exchange between the local population and itinerant groups was likely peaceful. The most identifiable outside influence is of Scandinavian origin as the intermittently travelling groups brought their archaeologically identifiable customs (Sperling 2016), such as the emergence of stone ship burials, hoarding practices, and the finds in the Staldzene (Vasks, Vijups 2004) and Tehumardi (Sperling 2013) hoards. Furthermore, the bronze casting indicates the existence of at least unidirectional communication between the two coasts of the Baltic Sea as the foreign forms observed in the refractories represent a region of one-sided influence. The appearance of brushed pottery in W Baltic sites is regarded as another argument for the existence of circum-Baltic contacts (Jaanusson 1981). Sites with extraordinary large quantities of brushed pottery, for example, up to 64\% at Darsgärde (Sweden; ibid, p. 51 , table 9), compared to rusticated pottery, which is common in the W and S Baltic, could be indicative of groups of people transported from the Eastern to the Western side of the Baltic Sea. Researchers have considered the reasons for people moving in both directions to be related to demographic pressure, economic crises, and cultural interactions (Wehlin 2013; Sperling 2016); some discuss the possibility of the acquisition of slaves in a regionally dispersed economy, an important component of the so-called maritime mode of production and the Nordic Bronze Age (Ling et al. 2018). Whatever the reason, it is clear that communication was bi-directional rather than uni-directional judging from the combined ceramic and metallurgical evidence.

The doubling of metal consumption during the Late Bronze Age as well as hoards and bronze casting in the SE Baltic are economically significant but highly dependent on the existence of communication networks. Knowledge of the concept of bronze casting 
and acquisition of the true skill are two different processes. The casting of axes and spearheads indicates a higher metallurgical knowledge than is expected from a local community just starting to become familiar with the concept of casting bronze. Long-term metallurgical activity requires a steady supply of bronze, or copper ${ }^{11}$ and tin, and for a secure transition of knowledge between different generations (Radivojevič 2015). The amount of bronze that was circulating in the SE Baltic (Luchtanas, Sidrys 1999) was insufficient and differentiated, i.e. highly dependent on a supply of metal by both direct Scandinavian importation and bronze production or on the movement of metal by the Sambian Barrow culture. The eastern influence in the SE Baltic Late Bronze Age is less tangible. A supply of bronze may be indicated by the hoards such as those at Staldzene or Littausdorf (Kaliningrad District, Russia). The semimanufactured ring-shaped artefacts in the former hoard could be interpreted as ingots; however, there is sparse evidence for any consideration of a steady circulation of bronze in the region.

Knowledge about its circulation is shown by a limited, specialised activity, which corresponds with the hypothesis of itinerant bronze casters. Moreover, they may have been the ones importing the bronze and later casting it as axes or other objects. Tied together, ring-shaped ingots ${ }^{12}$ could have functioned as a comfortable form for transportation. However, the hypothesis of their standardisation based on size or weight value (Sperling 2014) is underrepresented in the archaeological data. Casting moulds for ringshaped artefacts differ from one another (Čivilyte 2014, p. 102, pav. 81, 82), ranging from 6 to $15 \mathrm{~cm}$ in diameter and 5 to $12 \mathrm{~mm}$ in thickness with no indications of standardized practices. Previous considerations for the Scandinavian weight system (Malmer 1992) are based on chronologically separate, selective artefact groups and indicate possible standards based on a Mediterranean influence. Even if it was true for several groups of finds, the weight of the artefacts transported to the SE Baltic lacks evidence of standardization. We caution against the uncritical adoption of the standardization concept in metallurgical studies as the hypothesis has significant implications for the theoretical model of a society with centralization that would include adoption of weight systems and notions of monetary value in most socio-economic interactions spreading from the centres to the peripheries. This situation would present a societal model very similar to statehood, which we doubt existed in the Nordic Bronze Age. The data on the crucible volumes presented by L. Melheim et al. (2016; Melheim 2018) are coincidental and, in fact, based on impossible conditions, i.e. the upper limit for a crucible's estimated capacity, which corresponded to five to ten (Jantzen 2008, p. 197) times Malmer's estimated weight unit of $107.07 \mathrm{~g}$. The impossibility of this standard to fill a crucible to the upper limit has been shown by experimental studies (Podènas, Babenskas 2017; Luchtanas et al. 2019). These demonstrate that solid ingots completely filling a crucible's volume after liquefaction, occupy only a $1 / 4-1 / 3$ of the crucible. Therefore, the standardisation of the weight was falsely transferred to the common metallurgical practices in the Northern European Bronze Age. Nordic influence in the region was significant, but the transmission of knowledge and customs was limited to the actual communication and exchanges between the communities in the coastal zone. Thus, it is doubtful that bronze casting was taught to local communities and the itinerant

${ }^{11}$ Among the finds from Littausdorf, Kr. Fischhausen (Zorina, raj. Primorsk) hoard, there is one copper rod ingot (Čivilytė 2014, p.158, pav.114).

12 The analogies for a ring-shaped ingot could be semi-finished armbands or neck rings; however better proof for ingots of this shape was found in the Långbro (Södermanland, Sweden) hoard dating to 900-700 BC, which included an object containing over 98\% tin (Ling et al. 2014, p.114, Fig.4, p.118, Table 2). 
bronze casters in question are more likely to be of Nordic origin than local as other traditions, such as the burial customs and the dominant pottery styles, were not adapted by the SE Baltic communities.

Lusatian influence is less archaeologically tangible in the investigation of the SE Baltic communication networks. Scandinavian and Lusatian pottery traditions were quite similar; nevertheless in the W Baltic sites, clear Lusatian influences are found, but sparsely and not in high frequencies (Jaanusson 1981). Therefore, it is difficult to interpret the appearance of early rusticated pottery in the SE Baltic coastal sites as it could have come either from the Lusatian or the Scandinavian territories. Lusatian territory could be considered the nearer region and thus a more likely origin of influence, but it is more difficult to find better arguments for their involvement in circum-Baltic contacts because the Scandinavian influence is more tangible archaeologically and is definitively active during the Late Bronze Age. The community that settled the Åland archipelago and formed the distinctive rough Otterböte style pottery differed from those of coastal Finland and Estonia where brushed pottery was common and communities further inland in Finland which were also distinguished by textile-impressed pottery (ibid 1981, p. 128-130, Fig. 59). The Åland islands seem to have been settled by communities particularly invested in the $\mathrm{N}$ circum-Baltic communication network, but the pottery influences indicate both Lusatian and Scandinavian traits. Thus, Baltic Sea coastline communication had been formed by all the participating parties in the region as the coastline settlements absorbed some of the influences from both intermittently moving groups and inland settlements.

\section{Interregional Communication Networks}

KAM type axes transcend beyond the circumBaltic area and make areat source in the discussion of further interregional communication between Scandinavia and the Volga-Kama regions, which are separated by roughly $2000 \mathrm{~km}$. This presents an important phenomenon as the majority of the casting moulds for KAM type axes are distributed far from their main consumption areas (Fig. 10), which are coincidently concentrated in the SE Baltic. This indicates a separation of the production zones from the consumption areas. KAM type axes, including the classic Mälar type (VIIb1-a according to Kuz'minych's (1996) typology) and their Nordic variations, are all individual as no two identical artefacts exist. For example, the Balsmyr (Denmark) hoard represents 15 similar, but slightly different KAM type axes, 1 of which is distinguished by triangle decorations above the horizontal lines (Antoniewicz 1955, tab.XXXIV:2). The motif is apparent in axes found in Lithuania (Merkevičius 2011, p. 145, pav. 253), Belarus (Čivilytè 2014, III lent. 18), Estonia (Paavel 2017, p. 29, Fig. 2:13), and Russia (Халиков 1977, p. 113, рис. 42:17). Therefore, the Balsmyr axe represents decorations inherent for two regions far away from each other. In addition to this, it seems likely that the type was not mass-produced. Most of the known casting moulds are made from clay. Soapstone casting moulds in Northern Europe are rare (Melheim 2015, p. 196, Fig. 4) and one exceptional bronze casting mould for a KAM axe was found in the Sieniocha river valley (Poland; Kłosińska, Sadowski 2017). By definition, KAM axes link artefacts with different shapes and decorations, from long-necked axes decorated with horizontal lines even with the loop and intersected by one or more vertical lines to long-necked axes without any decoration or short-necked axes with horizontal lines as decoration. It is, therefore, important to point out that KAM is not a uniform axe type, but a hybrid one (Melheim 2015, p. 196). The casting moulds for KAM type axes found in SE Baltic settlements are smaller and shorter than the bronze axes found in Scandinavia and are regarded by some researchers 


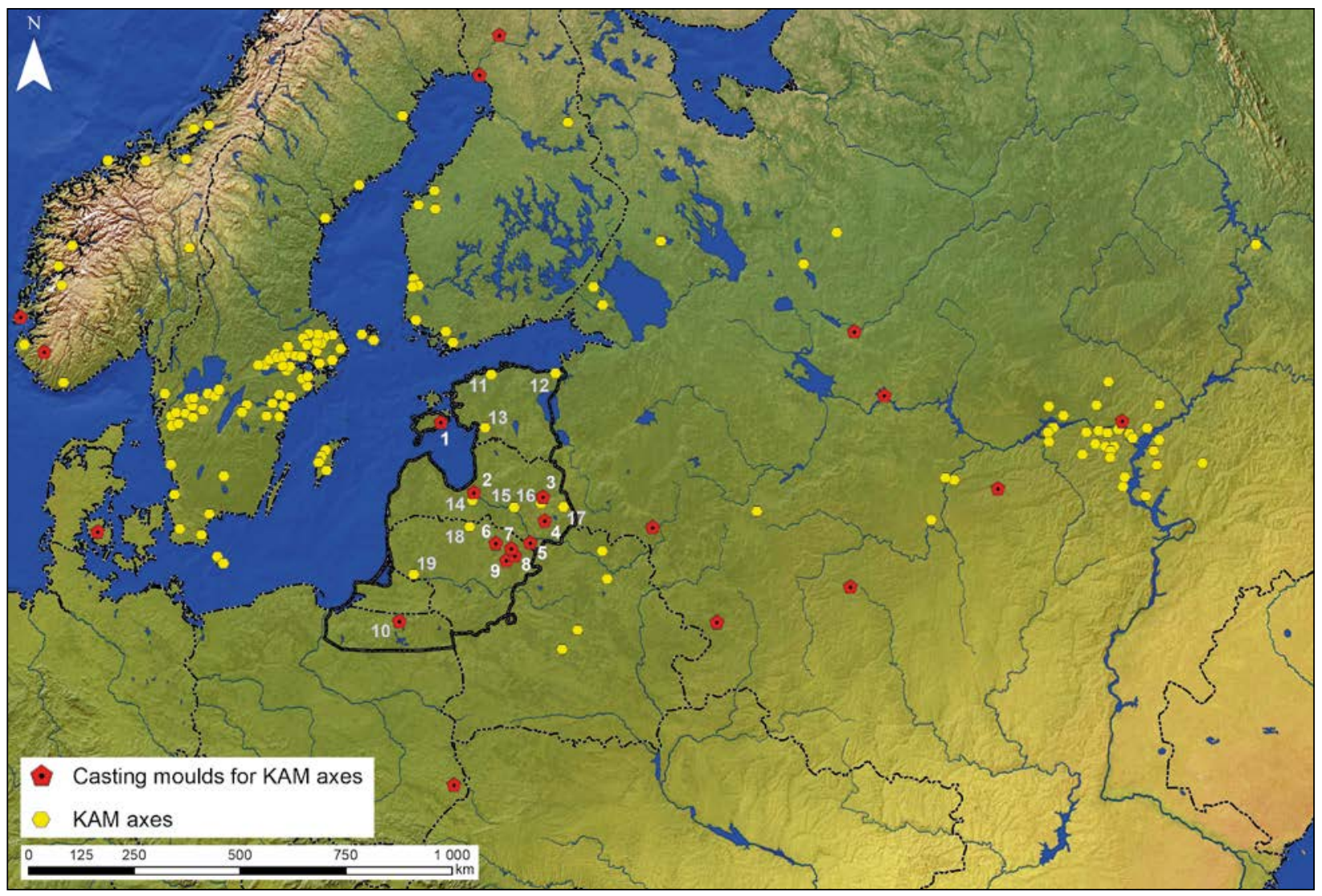

Fig. 10. The locations of KAM type axes (yellow hexagons) and casting moulds for them (red pentagons). Clay casting moulds in the studied (marked on the map) region: 1 - Asva; 2 - Kivutkalns; 3 - Brikuḷi; 4 - Rušenica; 5 - Baltkāji; 6 - Kereliai; 7 - Vosgèliai; 8 - Garniai I; 9 - Narkūnai; 10 - Tarławki. Bronze KAM-type axes in the same territory: 11 - Astangu; 12 - Mummassaare (Vaivara); 13 - Silla; 14 - Kḷanǵukalns; 15 - Krustpils; 16 - Lubāns; 17 - Ludza; 18 - Vaškai; 19 - Rambynas. After Kuz’minych 1996; Юшкова 2011; Čivilyte 2014; Paavel et al. 2019; supplemented by VP. Drawing by V. Podènas.

to form a locally adapted type (Luchtanas 1981, p. 11; Luchtanas, Sidrys 1999, p. 18). These casting moulds reflect adaptations of foreign impulses in the metalpoor region. The stylistic features of KAM axes are recognizable as distinguishable traits. The specific placement of the loop in line with the decorations on KAM bronze axes forms an informational code that enriched the SE Baltic culture and had specific meanings, which include notions of status (Kuz’minych 1996; Hjärthner-Holdar 1998), for their creators and bearers.

KAM axes and the casting moulds for them delineate possible routes between the two most extensive consumption zones in Nordic Bronze Age and the Volga-Kama region. However, the discussion has entertained different possibilities for their use in the area between these regions. Traditional views have considered KAM axes to have originated in central Sweden, where it received the name Mälar type axe, and spread throughout the Nordic Bronze Age world as well as to the Volga-Kama region (Tallgren 1911; 1937, pp. 30-36; Brøger 1918; Childe 1943; Meinander 1954, p. 37 cited in Melheim 2015, p. 194). This view was abandoned in favour of Russian provenance after typological studies concluded that the stylistic features of the Russian axes outnumber the inherent ones of the Swedish axes (ibid). Furthermore, this hypothesis was supported by casting moulds found in 
the Volga-Kama basin (Халиков 1977, p. 166, рис. 43). Thus, for a time the discussion experienced a radical turn to consider the metal trafficking from the Urals and Kazakhstan (Kresten 2005, cited in Melheim 2015 , p. 194) to Scandinavia. In the discussion, the growing evidence of casting moulds for these axes has led to considerations of local production in the E Baltic as well as NW Russia with significant influence from eastern and western metallurgical centres (Luchtanas 1981; Юшкова 2011). We argue that it indicates an exchange model in which itinerant metallurgists with an accompanying party organized inland expeditions to exchange locally desired metal objects. The Daugava river route, which runs towards the Valdai Hills, is the longest Baltic Sea tributary in the study region. These hills mark a division between the drainage basins of the Baltic, Black, and Caspian Seas; thus the River Daugava joining the Rivers Volga and Dnieper in the same region became the most important inland route via the SE Baltic in prehistory. Other possible routes led via Karelia, although, admittedly, they must have been harder to use. Finally, the debate on the provenance of Scandinavian axes was furthered by lead isotope analyses to conclude that there are no lead isotope consistencies with the deposits in the Urals (Ling et al. 2014; Melheim 2015). Despite the fact that only several of KAM axes had been the object of a metal provenance analysis, it is unlikely that bulk importation from the Volga-Kama occurred in the Nordic Bronze Age as the transitional regions would have experienced more of an eastern influence, not vice versa.

The existence of wider interregional communication networks during the Bronze Age is represented by metalwork (Lang 2007; Čivilyte 2014). The bronze casting practices in SE Baltic are chronologically limited and undoubtedly include Scandinavia and, to an unknown extent, the Lusatian culture. From the Early Bronze Age, the Sambian Barrow culture possessed continuous leverage in region's communications and metal importation (Luchtanas, Sidrys 1999). However, the appearance of Scandinavian settlements in Courland (Граудонис 1967) and on Saaremaa Island (Lang 2007, pp. 164166), including probably other locations where stone ship burials have been found, have challenged the existing mediator-based metal movement and presented new forms of exchange. Therefore, a more direct communication with local communities had developed after the region completed a transition to full agriculture and crop cultivation intensified (Minkevičius et al. 2019). Moreover, a northern route via the Åland archipelago had also been employed and established an intriguing case of mixed coastal Baltic traditions represented by Otterböte style pottery (Jaanusson 1981, p. 53) that combined features of brushed and rusticated pottery (Salo 1984) as well as supplemented the assemblages with burnished and textile-impressed vessels.

Finally, it seems that KAM axes indicate another argument in the search for economic impulses in the SE Baltic, but the hypothesis derives from vast quantities of differentiated data in which the totality of the bronze casting debris holds together an argument in conjunction with research into hoarding practices, burial sites, settlement practices, agricultural development, etc. The model presented in this paper is what we consider the likeliest based on the current knowledge, but it does not mean that the discussion is over or that newly obtained evidence could not challenge this narrative.

\section{CONCLUSIONS}

The earliest metallurgy in the region consists of ambiguous evidence dating to the Early Bronze Age and a significant amount of data for the Late Bronze Age. Recurrent bronze casting in the SE Baltic emerged in the hilltop settlements of coastal areas, in the vicinity of the River Daugava, the SE Latvian and NE Lithuanian uplands, and the Masurian Lakeland 
as these regions constituted secure areas for bronze production, stock accumulation, and barter. Bronze production sites were established in connection with the communication networks between the hilltop settlement communities and the Scandinavian settlements in the SE Baltic coastal regions, which are indicated by stone ship burials in Courland, S Saaremaa, N Estonia, and the Sambian Peninsula.

Casting moulds with an identifiable cast artefact type are scarce and most of them are attributed to axes, most distinguishable as the KAM type but others unidentifiable as to the particular type. Most of the SE Baltic assemblage consists of fragments of casting moulds for the ring-shaped artefacts. As exemplified by the Staldzene Hoard, these armbandlike rings or neck rings were not necessarily finished and probably functioned as ingots. Other cast objects in the SE Baltic, to a significantly lesser degree, consisted of spearheads. One casting mould from Asva had been used to produce a disc-shaped pin of the Härnevi-type. The lack of indigenous metalwork and the one-sidedness of the origin indicate that the original bronze casters in the region were likely not of SE Baltic origin, but should instead be associated with foreign settlements established in the coastal regions.

The most numerous collections were discovered in coastal hilltop settlements, Asva on Saaremaa Island, and Kivutkalns on the lower Daugava. These sites were likely to have been in continuous contact and exchange with the Scandinavian settlements on Saaremaa Island and Courland. Settlements further inland were mostly impacted in the vicinity of the significant Daugava river route and the Masurian Lakeland but yielded significantly smaller collections. The only exceptions are the accumulations at the Brikuli, Narkūnai, and Tarławki hilltop settlements that could have served as further mediators in local exchange networks. Bronze production waste was unambiguously left from the episodic work of a periodically available caster. The itinerant metallurgist hypothesis is appropriate for all of the discussed cases that display differentiation in the frequency of casting recurrences at the same site. However, their activities without an accompanying party for security or the possibility for barter are unlikely.

The earliest bronze casting debris indicates the existence of several levels of overlapping communication systems. In the SE Baltic case, it represents only the communities that were in contact with itinerant groups of people that moved intermittently and were of Scandinavian origin. Communication existed between the Scandinavian settlements and the most important established hilltop settlements that had accumulated enough desired commodities for an exchange to take place for bronze objects. The unenclosed settlements further inland unenclosed are, however, left outside these relations. But this does not mean that more local economic interaction systems did not exist. As well as the intraregional SE Baltic communication networks, bronze casting, together with other evidence, indicates a circum-Baltic and further interregional movement of metals and commodities. The SE Baltic Late Bronze Age is distinguished as a temporal case because the emergence of recurrent bronze casting and the doubling of metalwork created a stimulus for societal development.

\section{Acknowledgements}

We would like to thank the National Museum of Lithuania, the Vytautas the Great War Museum, the National History Museum of Latvia, Tallinn University, the State Archaeological Museum in Warsaw, and the Museum of Warmia and Masuria in Olsztyn for letting us review their archaeological collections. We are grateful to Aleksiejus Luchtanas for his help in consultations during the early stages of this study. We would also like to thank Christopher Troskosky for providing a language revision of this paper. 


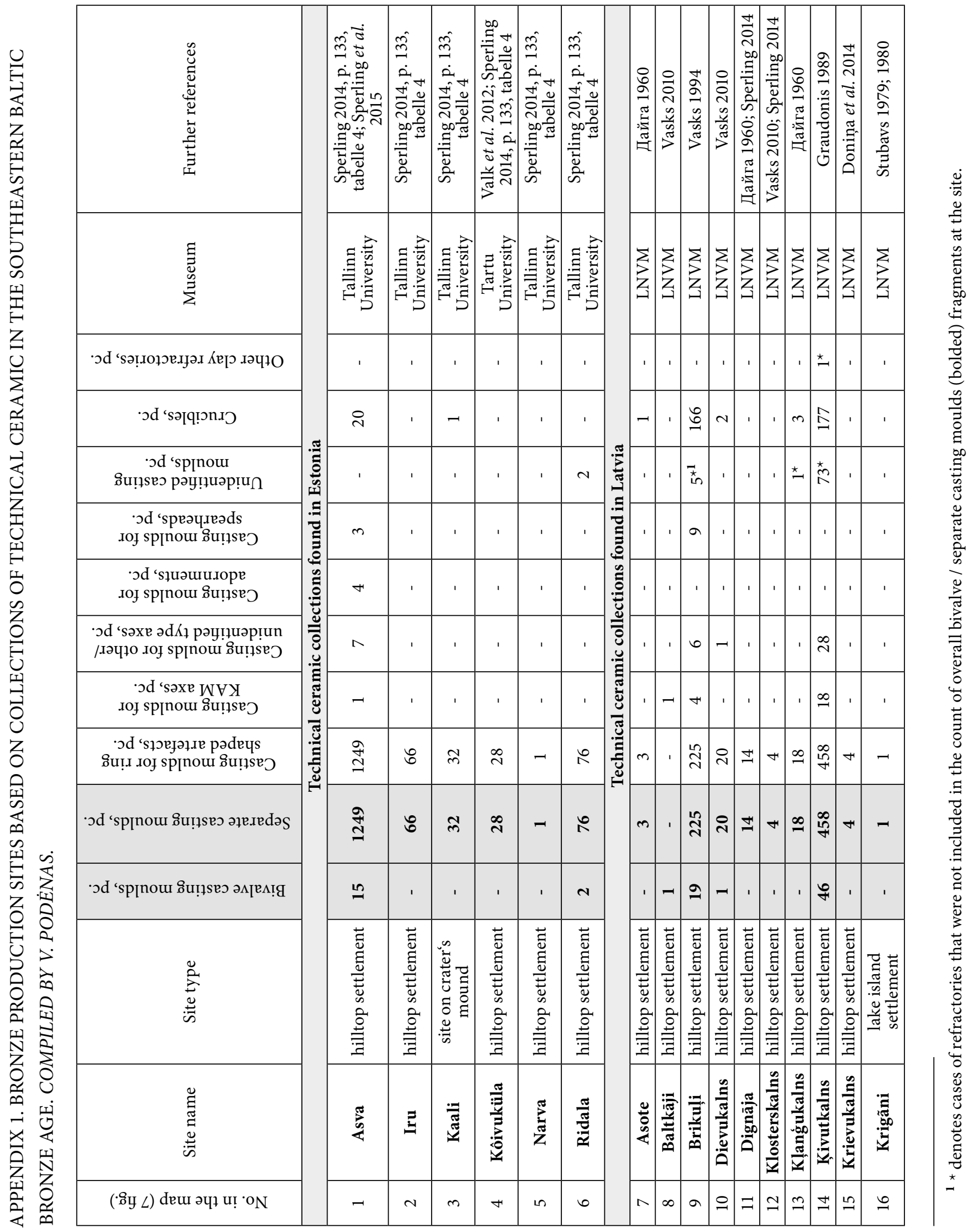




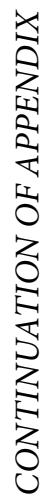

\begin{tabular}{|c|c|c|c|c|c|c|c|c|c|c|c|c|c|c|c|c|c|c|c|c|c|c|c|}
\hline 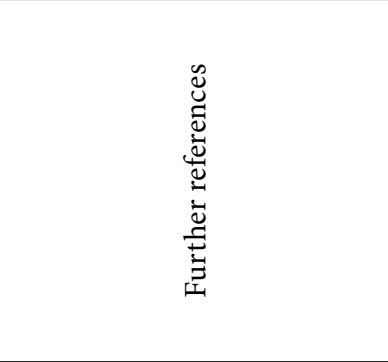 & 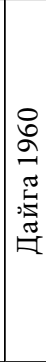 & 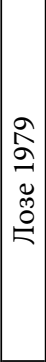 & 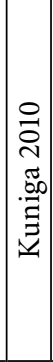 & 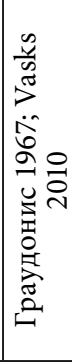 & 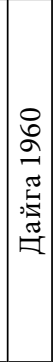 & 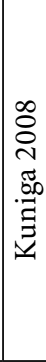 & 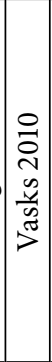 & 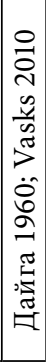 & 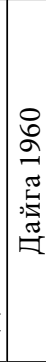 & 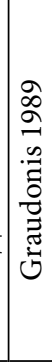 & & 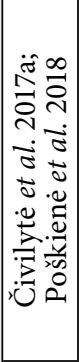 & 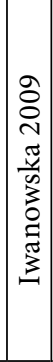 & 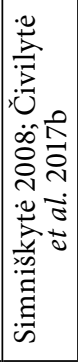 & 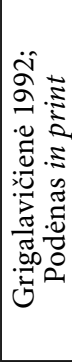 & 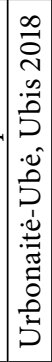 & 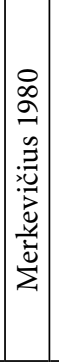 & 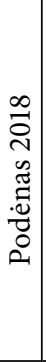 & 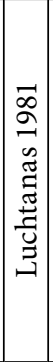 & 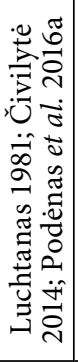 & 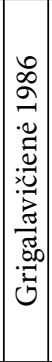 & 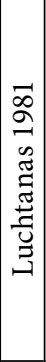 & 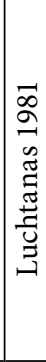 \\
\hline 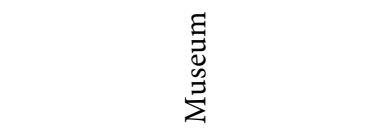 & 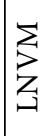 & 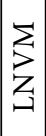 & $\mid$\begin{tabular}{l}
$\Sigma$ \\
$z$ \\
$z$ \\
\hdashline
\end{tabular} & 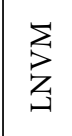 & 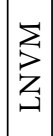 & 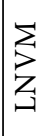 & $\mid \begin{array}{l}\Sigma \\
z \\
z\end{array}$ & 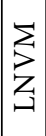 & 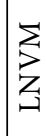 & $\mid \begin{array}{l}\sum_{3} \\
\text { 学 }\end{array}$ & & 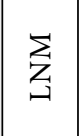 & $\sum_{\infty}^{\mathbb{1}}$ & 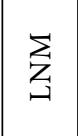 & 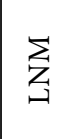 & $\sum_{Z}$ & 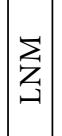 & $\sum_{3}$ & $\sum_{\infty}$ & $\underset{Z}{Z}$ & 吕 & $\mid \begin{array}{l}\Sigma \\
\vdots \\
\rho \\
\rho\end{array}$ & \\
\hline 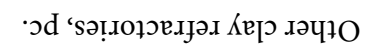 & ' & ' & ' & & ' & ' & ' & ' & ' & & & ' & ' & ' & & ' & ' & ' & ' & ' & ' & & \\
\hline 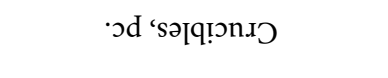 & - & $\simeq$ & tr & $\exists$ & ' & $\exists$ & - & ' & $m$ & 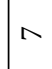 & $\pi$ & ' & ' & & in & - & $\sim$ & - & ' & $H$ & v & & \\
\hline 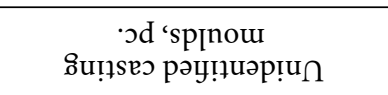 & $\neg$ & ' & ' & $\stackrel{\star}{\sim}$ & 1 & $\stackrel{\star}{-}$ & ' & ' & ' & ' & 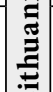 & ' & ' & ' & & ' & 1 & ' & ' & ' & ' & ' & \\
\hline $\begin{array}{l}\text { •od 'speəuırads } \\
\text { dof sp[now ou!̣sej }\end{array}$ & ' & ' & ' & 7 & ' & ' & ' & ' & ' & & 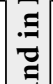 & ' & ' & ' & ' & ' & ' & ' & ' & ' & ' & & \\
\hline $\begin{array}{l}\text { ’d ‘słuəuulope } \\
\text { गof sp[now su!̣sej }\end{array}$ & ' & ' & I & & ' & ' & ' & ' & ' & ' & $\mid \begin{array}{l}0 \\
0 \\
0 \\
0 \\
0\end{array}$ & ' & ' & & & ' & ' & ' & ' & ' & & & \\
\hline 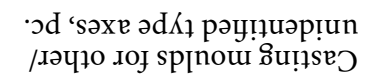 & ' & ' & ' & & ' & ' & ' & ' & ' & & : & 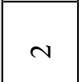 & $\sim$ & & & ' & 1 & - & ' & $\stackrel{10}{=}$ & $\neg$ & & \\
\hline 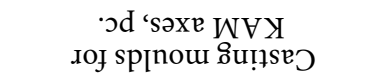 & ' & ' & ' & & 1 & 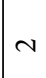 & ' & ' & ' & & 赔 & ' & ' & $m$ & - & ' & ' & ' & ' & 으 & 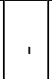 & 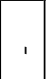 & $\begin{array}{lll}-1 & -1 & -1\end{array}$ \\
\hline 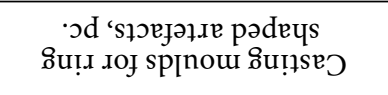 & f & ' & $v$ & ' & -1 & $\infty$ & ' & -7 & 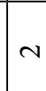 & 2 & :⿹ & $N$ & $\sim$ & ' & in & ' & $\sim$ & ' & s & Ln & 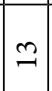 & in & - \\
\hline 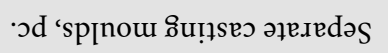 & F & ' & $N$ & ' & -7 & $\infty$ & ' & - & a & 2 & & N & $\omega$ & ' & in & ' & $N$ & ' & $n$ & in & 2 & in & - \\
\hline 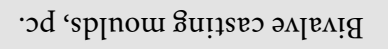 & 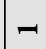 & ' & , & - & ' & 4 & ' & ' & ' & I & & $\mathrm{n}$ & $N$ & $m$ & 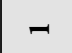 & ' & . & $\begin{array}{lll}-1 & -1 & -a\end{array}$ & ' & $\stackrel{10}{N}$ & - & & - \\
\hline 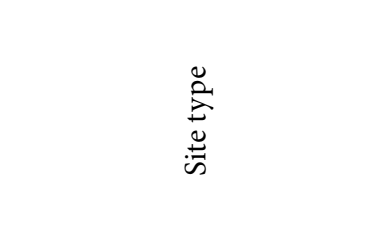 & 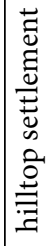 & 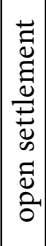 & 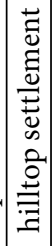 & 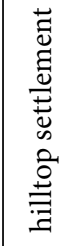 & . & 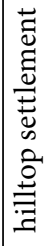 & 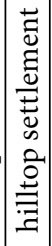 & 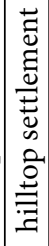 & 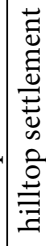 & 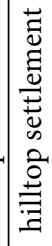 & & 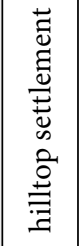 & 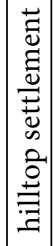 & 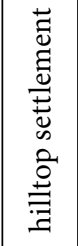 & 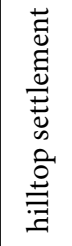 & 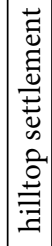 & 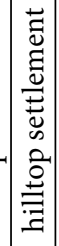 & 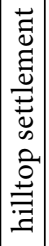 & 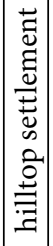 & 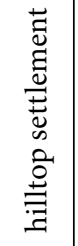 & 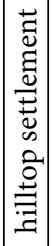 & 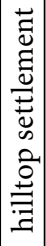 & 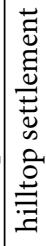 \\
\hline 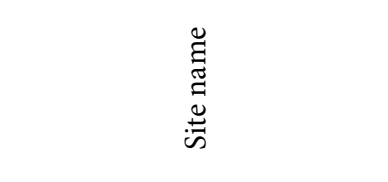 & 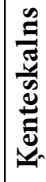 & 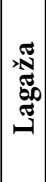 & 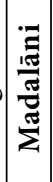 & 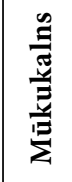 & 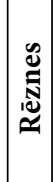 & 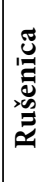 & 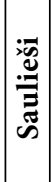 & 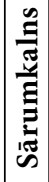 & 总 & 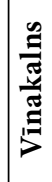 & & & 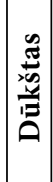 & 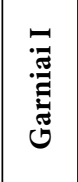 & 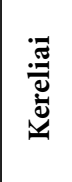 & 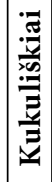 & 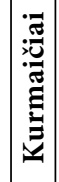 & 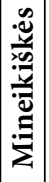 & 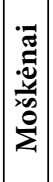 & 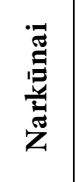 & 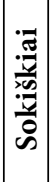 & 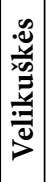 & 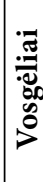 \\
\hline 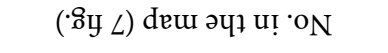 & 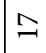 & $\stackrel{\infty}{-1}$ & 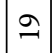 & 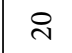 & $\vec{\sim}$ & $\tilde{N}$ & $\ddot{\sim}$ & $\stackrel{4}{d}$ & $\stackrel{2}{\sim}$ & i & & ஸे & $\stackrel{\infty}{\sim}$ & ৯ิ & m & $\vec{m}$ & $\tilde{m}$ & $\tilde{m}$ & m & $\stackrel{n}{m}$ & in & m & $\stackrel{\circ}{n}$ \\
\hline
\end{tabular}




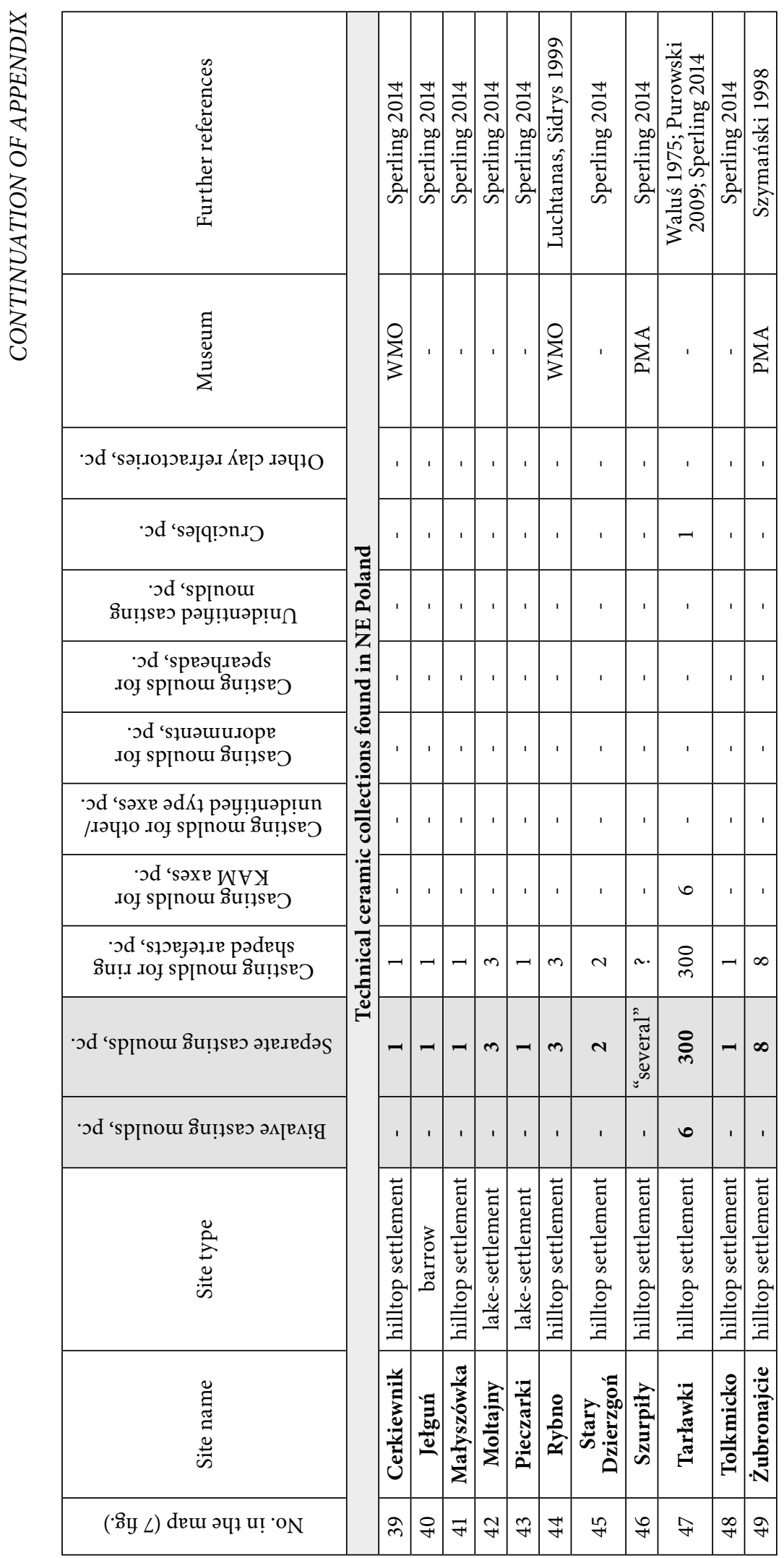




\section{REFERENCES}

Antoniewicz, W., 1955. Siekiery Brązowe Typu Mälar z Mińska na Białorusi. Wiadomośći Archeologiczne, XXII, 278-283.

Baudou, E., 1960. Die regionale und chronologische Einteilung der jüngeren Bronzezeit im Nordischen Kreis. (=Acta Universitatis Stockholmiensis, Studies in North-European Archaeology I). Stockholm: Almqvist \& Wiksell.

Bradley, R., 1985. Exchange and Social DistanceThe Structure of Bronze Artefact Distributions. Man, 20(4), 692-704.

Brøgger, W.C., 1918. Broncecelten fra Bøle nær porsgrund. En bestemmelse av strandlinjens høide under yngre bronsealder i den sydlige del av Kristianiafeltet. Oldtiden, VII, 37-63.

Čivilytè, A., 2004. Pagaminti tam, kad panaudotum? Keletas nežinomos bronzinès liejimo formos (Dovilai, Klaipėdos raj.) reikšmių. LA, 25, 221-232.

Čivilytè, A., 2014. Žmogus ir metalas priešistorèje: žvilgančios bronzos trauka. Vilnius: Diemedžio leidykla.

Čivilytė, A., Mödlinger, M., 2010. Bronzos amžiaus metalurgija: atkraštinių kirvių gamybos technologijos ir funkcijos klausimu. LA, 36, 121-152.

Čivilytè, A., Podènas, V., Vengalis, R., 2017a. Antilgès piliakalnis. ATL 2016 metais, 65-69.

Čivilytè, A., Podènas, V., Vengalis, R., 2017b. Garnių I piliakalnis. ATL 2016 metais, 69-73.

Childe, V.G., 1943. Archaeology in U.S.S.R. The Forest Zone. Man, 43, 4-9.

Dąbrowski, J., 1968. Zabytki metalowe epoki brązu między Dolna Wisła a Niemnem. Wrocław: Zakład Narodowy im. Ossolińskich.

Doniņa, I., Vasks, A., Vilka, A., 2014. Izrakumi Skrundas Krievu kalnā. In: Urtāns, J., Virse, I.L., eds. APL 2012-2013. Rīga: Nordik, 35-41.

Earle, T., Ling, J., Uhnér, C., Stos-Gale, Z., Melheim, L., 2015. The Political Economy and Metal Trade in Bronze Age Europe: Understanding Regional
Variability in Terms of Comparative Advantages and Articulations. European Journal of Archaeology, 18 (4), 633-657.

Gimbutas, M., 1965. Bronze Age Cultures in Central and Eastern Europe. The Hague: Mouton \& Co.

Graudonis, J., 1989. Nocietinātās apmetnes Daugavas lejtecē. Rīga: Zinātne.

Girininkas, A., 1987. Kretuono 1C gyvenvietes tyrinejimai 1987 metais. LIIR, F. 1, b. 1343.

Girininkas, A., 1994. Baltų kultūros ištakos. Vilnius: Savastis.

Girininkas, A., 2009. Lietuvos archeologija, I. Akmens amžius. Vilnius: Versus Aureus.

Graudonis, J., 1989. Nocietinātās apmetnes Daugavas lejtecē. Rīga: Zinātne.

Grigalavičienè, E., 1986. Sokiškių piliakalnis. $L A, 5,89-136$.

Grigalavičienè, E., 1992. Kerelių piliakalnis. $L A$, 5, 85-105.

Grikpėdis, M., Motuzaite Matuzeviciute, G., 2018. A Review of the Earliest Evidence of Agriculture in Lithuania and the Earliest Direct AMS Date on Cereal. European Journal of Archaeology, 21(2), 264-279.

Harding, A.F., 2000. European Societies in the Bronze Age. Cambridge University Press.

Harding, A., 2013. Trade and exchange. In: Harding, A., Fokkens, H., eds. The Oxford Handbook of European Bronze Age. Oxford University Press, 370-381.

Harding, A., Ostoja-Zagórski, J., Palmer, C., Rackham, J., 2004. Sobiejuchy: A Fortified Site of the Early Iron Age in Poland. Warszawa: the Institute of Archaeology and Ethnology of the Polish Academy of Sciences.

Hjärthner-Holdar, E., 1998. Samspel mellan olika regioner i Sverige och Rysland under yngre bronsålder sett utifrån järnteknologins införande. In: Løken T., ed. Bronsealder i Norden - Regioner og interaksjon. Foredrag ved det 7. norske bronsealdersymposium i Rogaland, 31. august - 3. september 1995. (=AmS-Varia, 33). Arkeologisk museum i Stavanger, 35-44. 
Iwanowska, G., 2009. Materiały z wykopalisk Ludwika Krzywickiego na litewskich grodziskach w zbiorach Państwowego Muzeum Archeologicznego w Warszawie. In: Bitner-Wróblewska, A., Iwanowska, G., eds. Bałtowie i ich sąsiedzi. Marian Kaczyński in memoriam. Warszawa: Państwowe Muzeum Archeologiczne, 261-292.

Jaanusson, H., 1981. Hallunda. A Study of Pottery from a Late Bronze Age Settlement in Central Sweden. Stockholm: Statens Historiska Museum.

Jantzen, D., 2008. Quellen zur Metallverbreitung im Nordischen Kreis der Bronzezeit (=Prähistorische Bronzefunde, XIX (2)). Stuttgart: Franz Steiner Verlag.

Jockenhövel, A., 1986. Struktur und Organisation der Metallverarbeitung in urnenfelderzeitlichen Siedlungen Süddeutschlands. Veröff. des Museums für Ur- und Frühgeschite Potsdam, 20, 213-234.

Kienlin, T.L., Korczyńska, M., Cappenberg, K., 2014. Alternative Trajectories in Bronze Age Landscapes and the 'Failure' to Enclose. In: Kienlin, T.L., Valde-Nowak, P., Korczyńska, M., Cappenberg, K., Ociepka J., eds. Settlement, Communication and Exchange around the Western Carpathians. Oxford: Archaeopress, 159-200.

Kłosińska, E.M., Sadowski, S., 2017. Long-distance connections of the south-eastern peripheries of the Lublin region at the time of the Lusatian culture in the light of archival and newly discovered materials. Sprawozdania Archeologiczne, 69, 391-408.

Kresten, P., 2005. Analysis of LBA celts from the collections of the Museum of Nordic Antiquities, Uppsala University: project 'Iron technology - a successful innovation. From bronze to iron in Scandinavia and Greece'. Activity Report 2000/2001, Geoarchaeological Laboratory, Department of Archaeological Excavations, UV Uppsala. Central Board of National Antiquities, Uppsala, 36-48.

Kuijpers, M.H.G., 2008. Bronze Age metalworking in the Netherlands (c.2000-800 BC): a research into the preservation of metallurgy related artefacts and the social position of the smith. Leiden: Sidestone Press.
Kuniga, I., 2008. Arheologiskie izrakumi Rušenicas pilskalnā. In: Vilcāne, A., ed. APL 20062007. Rīga: Zinātne, 46.

Kuniga, I., 2010. Madalānu pilskalns, ciems un kapulauki 1. g. t. pr. Kr. - 13. gs. Jēkabpils: SIA "Jēkabpils drukātava".

Kuz'minych, S.V., 1996. Osteuropäische und fennoskandische Tüllenbeile des Mälartyps: Ein Rätsel der Archäologie. Fennoscandia archaeologica, 13, 3-27.

Lang, V., 2007. The Bronze and Early Iron Ages in Estonia (=Estonian archaeology, 3). Tartu University Press.

Ling, J., Stos-Gale, Z., Grandin, L., Billström, K., Hjärthner-Holdar, E., Persson, P. O., 2014. Moving metals II: provenancing Scandinavian Bronze Age artefacts by lead isotope and elemental analyses. Journal of Archaeological Science, 41, 106-132.

Ling, J., Earle, T., Kristiansen, K., 2018. Maritime Mode of Production: Raiding and Trading in Seafaring Chiefdoms. Current Anthropology, 59 (5), 488-524.

Lõugas, V., 1966. Zur Geschichte der bronzezeitlichen Metallindustrie in Estland. In: Moora, H., Selirand, J., eds. Pronsiajast varase feodalismini. Uurimusi baltimaade ja naaberalade archeoloogiast. Tallinn: ENSV Teaduste Akadeemia Ajaloo Instituut, Eesti Raamat, 102-113.

Luchtanas, A., 1981. Žalvario apdirbimas ankstyvuosiuose Rytų Lietuvos piliakalniuose. $L A, 2$, 5-17.

Luchtanas, A., Sidrys, R.V., 1999. Bronzos plitimas rytiniame Pabaltijo regione iki Kristaus. Archaeologia Lituana, 1, 15-55.

Luchtanas, A., Podènas, V., Bebenskas, E., 2019, spaudoje. Romėniškojo laikotarpio ritinis smeigtukas: nuo archeologinio radinio iki rekonstrukcijos. In: Luchtanienè, D., sud. Eksperimentine archeologija: Lietuvos materialaus paveldo rekonstrukcija, III. Vilnius: Akademinè leidyba.

Malmer, M., 1992. Weight systems in the Scandinavian Bronze Age. Antiquity, 66, 377-388. 
Meinander, C.F., 1954. Die Bronzezeit in Finnland (=Suomen Muinaismuistoyhdistyksen Aikakauskirjal Finska Fornminnesföreningens Tidskrift, 54). Helsinki: Helsingfors.

Melheim, L., 2015. Late Bronze Age axe traffic from Volga-Kama to Scandinavia? The riddle of the KAM axes revisited. In: Hauptmann, A., D. Modarressi-Tehrani, D., eds. Archaeometallurgy in Europe III. (=Der Anschnitt. Beiheft 26). Deutsches Bergbau-Museum Bochum, 193-202.

Melheim, L., Prescott, C., Anfinset, N., 2016. Bronze casting and cultural connections: Bronze Age workshops at Hunn, Norway. Praehistorische Zeitschrift, 91 (1), 42-67.

Melheim, L., 2018. Weight units and the transformation of value: approaching premonetary currency systems in the Nordic Bronze Age. In: Brandherm, D., Heymans, E., Hofmann, D., eds. Gifts, Goods and Money. Comparing currency and circulation systems in past societies. Oxford: Archaeopress, 67-83.

Meinander, C.F., 1954. Die Bronzezeit in Finnland (=Suomen muinaismuistoyhdistyksen aikakauskirjal Finska fornminnesföreningens tidskrift, 54). Helsinki: Suomen Muinaismuistoyhdistys.

Merkevičius, A., 1980. Kurmaičių (Kretingos raj.) piliakalnis. ATL 1978-1979 metais, 91-95.

Merkevičius, A., 2011. Ankstyvieji metaliniai dirbiniai Lietuvoje. Vilnius: Versus Aureus.

Minkevičius, K., Podėnas, V., Urbonaitė-Ubè, M., Ubis, E., Kisielienè, D., 2019. New evidence on Late Bronze Age agrarian intensification in the Southeast Baltic and the earliest AMS dates of Lens culinaris and Vicia faba. VHA. Prieiga per: https:// doi.org/10.1007/s00334-019-00745-2.

Neustupný, E., 1998. Structures and Events: the Theoretical basis of Spatial Archaeology. In: Neustupný, E., ed. Space in Prehistoric Bohemia. Praha: Institute of Archaeology.

Niesiołowska-Wędzka, A., 1991. Procesy urbanizacyjne w kulturze łużyckiej. In: Jaskanis, J., ed. Prahistoryczny gród w Biskupinie. Problematyka osiedli obranych na początku epoki żelaza. Warsaw: Państwowe Muzeum Archeologiczne, 57-80.

Okulicz, Ł, 1976. Osadnictwo strefy wschodniobałtyckiej w I tysiącleciu przed nasza era. Wrocław: Polska akademia nauk.

Olsen, J., Hornstrup, K.M., Heinemeier, J., Bennike, P., Thrane, H., 2011. Chronology of the Danish Bronze Age based on ${ }^{14} \mathrm{C}$ dating of cremated bone remains. Radiocarbon, 53 (2), 261-275.

Paavel, K., 2017. Pattern or random? Contextualising Estonian Bronze Age bronze stray finds on the landscape. $A B, 24,26-42$.

Paavel, K., Kriiska, A., Lang, V., Kulkov, A., 2019. Three bronze axes with wooden haft remains from Estonia. EJA, 23 (1), 3-19.

Pieczyński, Z., 1950. Formy i przybory odlewnicze z grodu kultury łużyckiej w Biskupinie. In: Kostrzewski, J., ed. III Sprawodzanie z prac wykopaliskowych w grodzie kultury łużyckiej w Biskupinie w powiecie żnińskim za lata 1938-1939 i 1946-1948. Poznań: Nakład Polskiego Towarzystwa Prehistorycznego, 113-131.

Piličiauskas, G., 2018. Virvelinès keramikos kultūra Lietuvoje 2800-2400 cal BC. Vilnius: Lietuvos istorijos institutas.

Piličiauskas, G., Kisielienè, D., Piličiauskienè, G., 2017. Deconstructing the concept of Subneolithic farming in the southeastern Baltic. VHA, 26 (2), 183-193.

Podènas, V., 2018. Mineikiškių piliakalnis. ATL 2017 metais, 89-91.

Podènas, V., in print. Skapiškio valsčiaus archeologinis paveldas. Kerelių piliakalnis. In: Jonušytė, A., sud. Skapiškis (Lietuvos valsčiai). Vilnius: Versmè.

Podenas, V., forthcoming. Emergence of Hilltop Settlements in the Southeastern Baltic: New AMS ${ }^{14} \mathrm{C}$ Dates from Lithuania and Revised Chronology. Submitted to Radiocarbon on 2019.01.29.

Podènas, V., Čivilytè, A., Bagdzevičienè, J., Luchtanas, A., 2016a. Technologiniai ir diagnostiniai Narkūnų techninès keramikos tyrimai. LA, 42, 151-189. 
Podènas, V., Luchtanas, A., Čivilytė, A., 2016b. Narkūnų piliakalnių ir papèdès gyvenvietès keramika: elgsenos atspindžiai. LA, 42, 191-241.

Podènas, V., Babenskas, E., 2017. Eksperimentiniai Narkūnų vèlyvojo bronzos amžiaus techninès keramikos tyrimai. In: Luchtanienè, D., sud. Eksperimentiné archeologija, II. Vilnius: Akademinè leidyba, 95-110.

Polanyi, K., 1963. Ports of Trade in Early Societies. The Journal of Economic History, 23 (1), 30-45.

Poškiene, J., Podènas, V., Luchtanas, A., 2018. Antilgès piliakalnis. ATL 2017 metais, 91-95.

Purowski, T., 2009. Ceramika z osady obronnej ludności kultury kurhanów zachodniobałtyjskich w Tarławkach, pow. Węgorzewo. In: Karczewska, M., Karczewski, M., eds. Ceramika Bałtyjska. Tradycje i wpływy. Materiały z konferencji, Białystok 21-23 Września 2005 roku. Białystok, 13-21.

Radivojevič, M., 2015. Inventing Metallurgy in Western Eurasia: a Look Through the Microscope Lens. Cambridge Archaeological Journal, 25 (1), 321-338.

Salo, U., 1984. Pronssikausi ja rautakauden alku. In: Blomstedt, Y., ed. Suomen historia, 1. Espoo: Weilin+Göös, 98-249.

Simniškytè, A., 2008. Daugailiai: žvilgsnis ị krašto praeitị. In: Jurkevičienè, R., Mališauskas, R., sud. Daugailiu kraštas ir žmonès. Utena: Utenos rajono savivaldybè.

Sörman, A., 2017. A place for crafting? Late Bronze Age metalworking in southern Scandinavia and the issue of workshops. In: A. Brysbaert, A., Gorgues, A., eds. Artisans versus Nobility. Leiden: Sidestone Press, 53-78.

Sperling, U., 2013. Der Bronzebruchhort von Tehumardi - Verstecktes Altmetall oder ritueller Weihefund? Ein Deutungsversuch am Erscheinungsbild der Bronzen. In: Johanson, K., Tõrv, M. eds. Man, his Time, Artefacts, and Places. Collection of Articles Dedicated to Richard Indreko. Muinasaja Teadus, 19. Tartu: TLÜ Ajaloo Instituut, TÜ ajaloo ja arheoloogia instituut, 261-316.
Sperling, U., 2014. Aspekte des Wandels in der Bronzezeit im Ostbaltikum. Die Siedlungen der Asvagruppe in Estland (=EJA, 18/2S). Tallinn: Estonian Academy of Sciences.

Sperling, U., 2016. Visitors to the other side. Some reflections on the Baltic Sea as a frontier and contact zone in late prehistory. In: Kannike, E.A., Tasa, M., eds. The Dynamics of Cultural Borders (=Approaches to Culture Theory, 6). University of Tartu Press, 106-132.

Sperling, U., Luik, H., 2010. Arrowheads, palisades and an attack scenario. Ridala Bronze Age hillfort revisited. $A B, 13,140-152$.

Sperling U., Lang V., Paavel K., Kimber A., 2015. Neue Ausgrabungen in der Bronzezeitsiedlung von Asva - vorläufiger Untersuchungsstand und weitere Ergebnisse. AFE 2014, 51-64.

Stubavs, A., 1979. Izrakumi Krīgānu ezersa-las apmetnē 1978. gadā. Zinātniskās atskaitas sesijas materiāli par arheologu (un etnogrāfu) pētījumu rezultātiem 1978, 72-77.

Stubavs, A., 1980. Krigānu arheolog̣iskās ekspedīcijas darbs 1979 gadā. Zinātniskās atskaitas sesijas materiāli par arheologu (un etnogräfu) pètījumu re-zultātiem 1979, 86-91.

Szafrański, W., 1950. Ciężarki tkackie i przęśliki z grodu kultury łużyckiej w Biskupinie. In: Kostrzewski, J., ed. III Sprawodzanie z prac wykopaliskowych w grodzie kultury łużyckiej w Biskupinie w powiecie żnińskim za lata 1938-1939 i 1946-1948. Poznań: Nakład Polskiego Towarzystwa Prehistorycznego, 132-160.

Szymański, P., 1998. Żubronajcie - przyczynek do badań nad wczesnożelazną ceramiką Suwalszczyzny. In: Karczewski, M., ed. Ceramika zachodniobałtyjska od wczesnej epoki żelaza do początku ery nowożytnej. Materiały $z$ konferencji - Białystok, 14-16 maja 1997. Białystok: Instytut Historii Uniwersytetu w Białymstoku.

Šnore, R., 1936. Izrakumi Doles pag. Klaṇǵu pilskalnā. Senatne un māksla, 1, 57-69. 
Šturms, E., 1947. Regionale Unterschiede in den Beziehungen zwischen dem Ostbaltikum und Skandinavien in der Bronzezeit. Contributions of Baltic University, 53, 1-10.

Tallgren, A.M., 1911. Die Kupfer- und Bronzezeit in Nordwestrussland. Die ältere Metallzeit in Ostrussland. (=Die Kupfer- und Bronzezeit in Nord- und Ostrussland, XXV:I). Helsinki: Finska fornminnesföreningens tidskrift.

Tallgren, A.M., 1937. The Arctic Bronze Age in Europe. Eurasia Septentrionalis Antiqua, XI, 1-46.

Urbonaitè-Ubė, M., Ubis, E., 2018. Kukuliškių piliakalnis. ATL 2017 metais, 115-119.

Valk H., Kama P., Olli M., Rannamäe E., 2012. Excavations on the hill forts of South-East Estonia: Kõivuküla, Märdi, Truuta and Aakre. AFE 2011, 27-46.

Vandkilde, H., 2007. Culture and Change in Central European Prehistory $6^{\text {th }}$ to 1st Millennium $B C$. Aarhus University Press.

Vandkilde, H., Hansen, S., Kotsakis, K., Kristianen, K., Müller, J., Sofaer, J., Sørensen, M.L.S., 2015. Cultural Mobility in Bronze Age Europe. In: Suchowska-Ducke, P., Reiter, S.S., H. Vandkilde, H., eds. Forging Identities. The Mobility of Culture in Bronze Age Europe, vol. 1. (=Bar International Series, 2771). Oxford: British Archaeological Reports.

Vasks, A., 1994. Brikuḷu nocietinātā apmetne: Lubāna zemiene vēlajā bronzas un dzelzs laikmetā (1000. g. pr. Kr. - 1000. g. pēc Kr.). Riga: Preses nams.

Vasks, A., 2007. Bronze-working centres in the system of social relations in the territory of Latvia during the early metal period. In: Merkevičius, A., ed. Colours of archaeology. Material culture and the society. Papers from the Second Theoretical Seminar of the Baltic Archaeologists (BASE) held at the University of Vilnius, Lithuania, October 21-22, 2005 (=Interarchaeologia, 2). Vilniaus universiteto leidykla, 65-77.

Vasks, A., 2010. Latvia as part of a sphere of contacts in the Bronze Age. $A B, 13,153-161$.
Vasks, A., Vijups, A., 2004. Staldzenes bronzas laikmeta depozits. Rìga: Fobo prints.

Waluś, A., 1975. Sprawozdanie z badań osiedla obronnego w Tarławkach, powiat węgorzewski. Rocznik Olsztyński, XI, 197-203.

Waluś, A., 1982. Dwa warsztaty odlewnictwa brązu z osiedla obronnego kultury kurhanów zachodniobałtyjskich w Tarławkach, woj. Suwalskie. Pamiętnik Muzeum Miedzi, 1, 243-248.

Wehlin, J., 2013. Östersjöns skeppssättningar. Monument och mötesplatser under yngre bronsålder. (=Gotarc Series B, 59.). Göteborgs universitet.

Граудонис, Я., 1967. Латвия в эпоху поздней бронзы и раннего железа. Рига: Зинатне.

Дайга, И.В., 1960. К вопросу о литейных формах и литейном деле на территории Латвии (до XIII в.). Советская археология, 3, 78-92.

Лозе, И.А., 1979. Поздний неолит и ранняя бронза Лубанской равнины. Рига: Зинатне.

Халиков, А. Х., 1977. Волго-Камье в начале эпохи раннего железа XIII-VI вв. до н. э. Москва: Наука.

Юшкова, М.А., 2011. Новые находки металлических изделий эпохи бронзы на Северо-Западе России. Тверской археологический сборник, 8 , 273-288.

\section{ABBREVIATIONS}

$\mathrm{AB}$ - Archaeologia Baltica

AFE - Archaeological fieldwork in Estonia

APL - Arheologu pētijumi Latvijā

ATL - Archeologiniai tyrinëjimai Lietuvoje

EJA - Estonian Journal of Archaeology

LA - Lietuvos archeologija

LNM - Lietuvos nacionalinis muziejus

LNVM - Latvijas Nacionālais vēstures muzejs

PMA - Państwowe Muzeum Archeologiczne w Warszawie

VDKM - Vytauto Didžiojo Karo Muziejus

VHA - Vegetation History and Archaeobotany WMO - Muzeum Warmii i Mazur w Olsztynie 


\title{
BRONZOS LIEJYBA IR KOMUNIKACIJA PIETRYČIŲ BALTIJOS JŪROS REGIONO BRONZOS AMŽIUJE
}

\author{
Vytenis Podėnas, Agnè Čivilytė
}

\section{Santrauka}

Ankstyviausia bronzos liejybos apraiška pietryčių Baltijos regione pavieniu atveju aptikta Vakarų Lietuvoje, datuojama II-III bronzos amžiaus periodais (1500-1100 m. pr. Kr.) pagal Doviluose rastą bronzinę liejimo formą ir ją atitinkantị kirvị, rastą Šiluteje. Tačiau pasikartojančiai vykdoma bronzos liejyba pasirodè gerokai vèliau, vèlyvajame bronzos amžiuje, kai vietiniai gyventojai užmezgè aktyvesnius kontaktus su Skandinavais, kurių ịkurtos gyvenvietės PR Baltijos regione lokalizuojamos pagal laivinius kapinynus Š Kurše, P Saremos dalyje, Š Estijos pakranteje ir Sembos pusiasalyje. Vietinès bendruomenès vèlyvajame bronzos amžiuje regione ịkūrè įtvirtintas gyvenvietes ir suformavo jų tinklą prie svarbiausių prekybinių kelių, esančių netoli jūros, prie Dauguvos upès, Pietryčių Latvijoje, šiaurès rytų Lietuvoje bei Mozūrijos ežeryne. Šiose ịtvirtintose gyvenvietėse buvo sukurtos sąlygos saugiam atsargu kaupimui, epizodinei metalo liejybai ir prekybinių mainų palaikymui.

Vèlyvuoju bronzos amžiumi datuojamos bronzos liejybos atliekos rastos 49 vietovèse. Daugiausia techninès keramikos aptikta pajūrio gyvenvietèse (Asva, Kivutkalns). Toliau, žemyninèje dalyje esančių Brikuli, Narkūnų ir Tarławki įtvirtintų gyvenviečių bendruomenès galejo būti suformavusios paklausesnę rinką gyvenviečių tinkle, tačiau daugumoje vietoviu j̇̌̌velgiama tik labai neryški epizodinè metalurginė veikla aptariamuoju laikotarpiu. Ištyrus 3325 radinius pietryčių Baltijos regione, tiksliau identifikuoti tik 4 gaminti radinių tipai, iš kurių dažniausiai pasikartojantys buvo liejimo formos KAM tipo kirviams. Kiti gaminti dirbiniai: Pfahlbautyp ietigalis, Harnëvi tipo smeigtukas ir panašūs kirviai ị Kalinówka Kościelna lobyje aptiktuosius. Taip pat retai gaminti neornamentuoti nedideli ietigaliai. Gamybos liekanos rodo aiškią Skandinavų metalo tradicijos įtaką, tuo tarpu tik Kalinówka Kościelna tipo kirviai galejo būti tiek Skandinavų, tiek Lužitènų tradicijose susiformavę dirbiniai. Visa techninè keramika aptikta tiriamajame regione neatspindi vietinių formų, todèl straipsnyje kvestionuojama vietinių metalurgų egzistavimo galimybè. Vietoje jos siūloma keliaujančių metalo liejikų hipotezè, kuriuos siejame su Skandinavų gyvenvietėmis. Ši hipotezè taip pat išreiškia naują komunikacijos ir mainų tipą bronzos amžiuje, kuris yra siejamas su specialistų su apsaugojančia ir pagelbejjančia palyda atvykimu ir trumpalaikiu apsistojimu vietinių gyvenvietėse. Jose igavus saugią terpę prekybai ir bronzinių dirbinių gamybai, buvo užpildoma vietinè gyvenvietės paklausa, išlaikant gamintojų pamėgtas dirbinių formas ir stilių. Tokiu būdu vèlyvajame bronzos amžiuje i pietryčių Baltijos regioną buvo atnešta daugiau bronzos, papildant tradicini per tarpininkus vystomą metalo kelią, greičiausiai tuo metu aktyviausiai veikiamą Lužitènų kultūros.

Remiantis archeologiniais metalo liejybos kompleksais įmanomi keli, vienas kitą papildantys bendruomenių komunikacijos būdai, kurių svarbiausias buvo tiesioginis ryšys su žmonèmis iš Skandinavijos. Šių interesas pietryčių Baltijos regione kartu su kitomis kultūromis atspindi kelių lygių, vienas kitą perdengiančių, komunikacijos tinklų egzistavimą vèlyvajame bronzos amžiuje. Vien bronzos gamyba atspindi vietinę regioninę komunikaciją tarp Skandinavų gyvenviečių ir įtvirtintų gyvenviečių, Baltijos 
jūros pakrantèse ịsikūrusių bendruomenių bendravimą bei Skandinavų - Volgos-Kamos regiono kontaktus. Šiuos komunikacijos lygius atspindi skirtingos rezoliucijos duomenys, tačiau šiandieninès sukauptos žinios leidžia juos konkretizuoti ir kelti naujas hipotezes apie regioną, kuriame po vèlyvos žemdirbystès pasirodymo vietinès bendruomenès aktyviai ịsijungè ị europinị bronzos amžiaus kontaktų tinklą bent trumpam I tūkstantm. pr. Kr. pirmoje pusejje. Pietryčių Baltijos regionas skyrèsi savo politine, kultūrine ir ekonomine pažanga nuo kaimyninių kultūrų, bei kartu sudaro labai įdomų atveji Europos priešistorès studijose.

\section{PRIEDAS}

1 priedas. Bronzinių dirbinių gamybos vietos remiantis techninès keramikos kolekcijomis, aptiktomis pietryčių Baltijos jūros regione. Sud. $V$. Podenas.

\section{ILIUSTRACIJŲ SAZRAŠAS}

1 pav. Pietryčių Baltijos jūros regiono ịtvirtintose gyvenvietèse rasti tigliai. Vietovès: 1 - Ķivutkalns (LNVM, VI120: 982); 2 - Asva (Talino universitetas, 4366: 1102); 3 - Kivutkalns (LNVM, VI120: 2103); 4 - Kivutkalns (LNVM, VI120: 829); 5 - Kereliai (LNM, AR 726: 132); 6 - Kereliai (LNM); 7 Ķivutkalns (LNVM, VI120: 1629). V. Podeno nuotr.

2 pav. Molinis kaištis dvipusei liejimo formai (LNVM, VI120:254). LNVM nuotr.

3 pav. Molinès liejimo formos žiedo formos dirbiniams. Vietovės: 1 - Sokiškiai (LNM, AR 211: 529); 2 - Brikul̦i (LNVM, A.12379: 450); 3 - Velikuškès (VDKM, 887: 237); 4 - Narkūnai (LNM, AR 594: 470; 492; 497; 754). V. Podeno nuotr.
4 pav. Molinès liejimo formos KAM tipo kirviams. Vietovès: 1 - Brikuḷi (LNVM, A.12405: 111; 282); 2 - Narkūnai (LNM, AR 594: 495); 3 - Baltkāji (LNVM, V.9082: 2); 4 - Vosgèliai (VDKM, 1378: 10); 5 - Kivutkalns (LNVM, VI120: 1244); 6 - Kivutkalns (LNVM, VI120: 203). V. Podeno nuotr.

5 pav. Molinè liejimo forma kirviui, panašaus i Kalinówka Kościelna lobio kirvių tipo. Rasta Dievukalns (LNVM, V.217: 366). V. Podeno nuotr.

6 pav. Molinès liejimo formos ietigaliams. Vietovès: 1 - Brikuli (LNVM, A.12379: 11, 275, 283); 2 Mūkukalns (LNVM, A.11848: 1041). V. Podèno nuotr.

7 pav. Bronzinių dirbinių gamybos vietovés pietrytiniame Baltijos jūros regione remiantis techninès keramikos kolekcijomis. Eiliškumas atitinka 1 priede esančią numeraciją. V. Podèno brèž.

8 pav. Techninè keramikos radimo vietos pagal vietovių tipus. $V$. Podèno diagrama.

9 pav. Reprezentatyviausia techninès keramikos kolekcija, rasta Ķivutkalns ịtvirtintoje gyvenvietèje. 1 - liejimo forma žiedo formos dirbiniui (LNVM VI:120: 2392; 2406); 2, 3 - liejimo formos KAM tipo kirviui (LNVM VI120: 2115; 1498); 4 - tiglis (LNVM VI120: 1449). LNVM nuotr.

10 pav. KAM tipo kirvių radimo vietovès (geltoni šešiakampiai) ir liejimo formos KAM tipo kirviams (raudoni penkiakampiai). Molinès liejimo formos aptiktos aptariamajame regione (žemèlapyje pažymètos ribos): 1 - Asva; 2 - Kivutkalns; 3 - Brikulı; 4 - Rušenica; 5 - Baltkāji; 6 - Kereliai; 7 - Vosgèliai; 8 - Garniai I; 9 - Narkūnai; 10 - Tarławki. Bronziniai KAM tipo kirviai toje pačioje teritorijoje: 11 Astangu; 12 - Mummassaare (Vaivara); 13 - Silla; 14 - Kḷanǵukalns; 15 - Krustpils; 16 - Lubāns; 17 Ludza; 18 - Vaškai; 19 - Rambynas. Pagal Kuz’minych 1996; Юшкова 2011; Čivilytė 2014; Paavel et al. 2019; su VP papildymais. V. Podèno brèž.

Gauta 20190801 Priimta 20190826 